\title{
Atlantic salmon in the Canadian Arctic: potential dispersal, establishment, and interaction with Arctic char
}

\author{
Miranda Bilous (i) Karen Dunmall (it)
}

Received: 28 January 2020/ Accepted: 20 June 2020/Published online: 21 July 2020

(C) The Author(s) 2020

\begin{abstract}
As the Arctic rapidly warms, sub-Arctic species such as the Atlantic salmon (Salmo salar) are expected to shift their distributions into the Arctic, potentially facilitating interaction with native Arctic species. Here, the possible dispersal and establishment of Atlantic salmon are considered in Canadian Arctic fresh waters containing Arctic char (Salvelinus alpinus), an important subsistence fish species. Available information about Atlantic salmon harvests in the Canadian Arctic was summarized to assess dispersal potential. Review and synthesis of published data were used to assess the suitability of the Canadian Arctic for Atlantic salmon colonization and the interaction potential of Atlantic salmon and Arctic char in Canadian Arctic fresh waters. Establishment of Atlantic salmon in Canadian Arctic thermal habitat was deemed possible, especially with rising freshwater temperatures. Overlap in habitat preferences and life cycles of Atlantic salmon and Arctic char, along with data on resource partitioning in sympatry, implied a possibility for interaction at multiple freshwater life stages. However, many data gaps were
\end{abstract}

M. Bilous

Department of Biological Sciences, University of

Manitoba, Winnipeg, MB, Canada

e-mail: bilousm@myumanitoba.ca

K. Dunmall ( $\square)$

Fisheries and Oceans Canada, 501 University Crescent,

Winnipeg, MB R3T 2N6, Canada

e-mail: karen.dunmall@dfo-mpo.gc.ca identified that inhibit further discussion and analysis. These considerations highlight the need for further study of these two culturally, ecologically, and economically important fish species, to address growing concerns and inform future management efforts.

Keywords Climate change - Freshwater habitat . Thermal tolerance $\cdot$ Distributional shifts $\cdot$ Sympatric populations $\cdot$ Species interactions $\cdot$ Salmonidae

\section{Introduction}

Anthropogenic climate warming has brought about distributional shifts and changes in abundance for a wide variety of terrestrial and aquatic species (IPCC 2014; Sunday et al. 2015). This warming is projected to continue increasing beyond 2100 for all but the most severe mitigation scenarios (IPCC 2014). As such, the global effects of climate change on species are expected to intensify, especially in the Arctic, which is warming more rapidly than the global average (IPCC 2014). The upper 75 meters of the global ocean have already warmed by $0.11{ }^{\circ} \mathrm{C}$ per decade from 1971 to 2010 , and ocean temperatures are projected to increase throughout the 21st century (IPCC 2014). Substantial changes in fresh water attributable to increasing air temperatures have also been documented (Chu et al. 2005; IPCC 2014). Ectotherms, 
such as fish, may be particularly vulnerable to these changes in climate, as they rely on ambient temperatures to regulate internal body temperature and maintain physical and chemical functions (Jeppesen et al. 2012). Though fish exist over a wide range of temperatures (from $-2.5^{\circ} \mathrm{C}$ to $44{ }^{\circ} \mathrm{C}$ ), no one species can tolerate this entire range (Somero and DeVries 1967; Heath et al. 1993; Elliott and Elliott 2010). Instead, different upper and lower thermal limits exist within and among species, populations, and life stages (Elliott and Elliott 2010). As global temperatures increase, however, these preferred thermal habitats are moving upward in elevation and to higher latitudes (Parmesan 2006; Sunday et al. 2012). Species inhabiting these rapidly changing environments must adapt, shift into more suitable habitat, or risk extirpation (Hein et al. 2012).

Many aquatic species are already experiencing changes in distribution, and multiple models have predicted range shifts in response to climate warming (Hein et al. 2012; Sunday et al. 2015; Poloczanska et al. 2016). Climate-related southward range extensions have occurred for many temperate marine fish species from southeast Australia (Last et al. 2011; Sunday et al. 2015), and multiple North Sea fish species have shifted their distributions northward with warming (Perry et al. 2005). In fresh water, fifteen British fish species have shown a mean distributional shift northward and upward in altitude over approximately 25 years (Hickling et al. 2006). These observations support the concept of niche-tracking (Tingley et al. 2009) through alterations of geographic ranges. Habitat modelling of many marine and freshwater fish species has similarly predicted poleward expansions and range shifts based on the changing climate (Chu et al. 2005; Fernandes et al. 2013; Hattab et al. 2014). These models and predictions of distributional shifts and their subsequent effects on ecosystems are important to biologists, local communities, and broader-scale economic activities (Sunday et al. 2015).

Anadromous species such as Pacific (Oncorhynchus spp.) and Atlantic salmon (Salmo salar) are experiencing both freshwater and marine habitat changes (Friedland et al. 2003; Chittenden et al. 2013; Dunmall et al. 2013). Pacific salmon species are expanding their range into the North American Arctic and are increasingly being harvested in subsistence fisheries in the western Canadian Arctic (Dunmall et al. 2013, 2018). Recent evidence suggests Atlantic salmon may also be shifting their marine distribution northward with warming temperatures (reviewed in Todd et al. 2011; Chittenden et al. 2013). The North American Atlantic salmon stock complex has seen an unprecedented decline over the past two decades that may be related to climate change (Friedland et al. 2003), and southern stocks on both sides of the Atlantic Ocean are experiencing reduced abundances and many are at risk of extirpation (COSEWIC 2010; ICES 2019). Atlantic salmon and other temperate fish species are expected to respond to changing thermal habitat with establishment of new spawning areas north of the current range limits, coincident with extirpation of southern populations (Reist et al. 2006a; Jonsson and Jonsson 2009).

Though poleward range shifts correlated with climate change have been recorded and predicted for many aquatic species, altered thermal regimes do not necessarily indicate the likelihood of colonization of these habitats. Climate-only models are known to overestimate future species distributions compared to models incorporating multiple habitat parameters, as successful dispersal and colonization depend on numerous characteristics of the novel habitat being well-matched with biological attributes of the establishing species (Fernandes et al. 2013; Hattab et al. 2014; Pess et al. 2014; Yoon et al. 2015). Indeed, multiple species-specific factors contribute to habitat suitability, including temperature, spawning site characteristics, and community interactions within the new habitat (Milner et al. 2008; Fernandes et al. 2013; Pess et al. 2014; Dunmall et al. 2016). In fish, habitat suitability is generally related to both trophic interactions and temperature (Pörtner and Farrell 2008), and establishment often depends on the narrow thermal limits of the highly vulnerable spawning and egg stages (Adams and Maitland 2001; Dunmall et al. 2016). While temperature-only models of colonization are less accurate, the importance of temperature in fish growth and metabolism (Pörtner and Farrell 2008) makes it a useful predictor for potential establishment that can inform future, more robust models (Dunmall et al. 2016).

Temperature and climate have long been recognized as drivers of speciation and colonization in freshwater and anadromous fish species (Milner and Bailey 1989; Makhrov et al. 2005; Waples et al. 2008; April et al. 2013). Cooling Arctic waters are thought to 
have contributed to the early Miocene divergence between the genera Salmo and Oncorhynchus (reviewed in Waples et al. 2008). The current distribution and genetic diversity of Atlantic salmon is related to its use of southern refugia during glaciation events and subsequent colonization of northern habitats as glaciers retreated (King et al. 2001; Makhrov et al. 2005; Jonsson and Jonsson 2011). Indeed, temperature is considered one of the biggest constraints on the present distribution of Atlantic salmon (MacCrimmon and Gots 1979) and will continue to affect Atlantic salmon stocks as climate warming continues (Jonsson and Jonsson 2009).

While other species are expanding their ranges northward, Arctic char (Salvelinus alpinus) are at risk of being reduced or displaced at the southern edge of their range as global temperatures increase and related changes ensue (Reist et al. 2006a, b; Vincent et al. 2013). Chu et al. (2005) predict a range contraction to the northeast Canadian Arctic, with $63 \%$ of the current range lost by 2050. Arctic char are declining in many European lakes (Jeppesen et al. 2012) and are predicted to lose $73 \%$ of their current range in Sweden by 2100 (Hein et al. 2012). Arctic fish species such as the Arctic char will likely be negatively affected by climate change through rising temperatures, habitat changes, and increased interactions with southern species expanding their ranges northward (Reist et al. 2006b). Specifically, Atlantic salmon are expected to shift northward and reduce or replace southern populations of Arctic char (Reist et al. 2006a; Jonsson and Jonsson 2009). Nielsen et al. (2013) suggest that Atlantic salmon will eventually move into and establish in the Arctic, but the complex interactions between climate change parameters and fish ecology complicate quantitative predictions, as detailed knowledge of population-habitat linkages is currently limited (Reist et al. 2006b).

With predictions of distributional shifts of subArctic species northward (Chu et al. 2005; IPCC 2014), it is necessary to identify the risks and opportunities associated with an increasing occurrence of Atlantic salmon in the Arctic. Arctic char populations are typically found in lakes with few or no other fish species (Klemetsen et al. 2003a), so the introduction of Atlantic salmon could dramatically change those ecosystems (Reist et al. 2006a, b). Indeed, fish introductions have been identified as one of the most widespread threats to Arctic char populations worldwide (Maitland 1995). Considering the importance of Arctic char to commercial, recreational and subsistence fisheries in the Canadian Arctic, the possible interactions of Arctic char and Atlantic salmon could have meaningful economic, ecological, and cultural impacts (Kristofferson and Berkes 2005). Atlantic salmon itself is greatly important to subsistence, recreational, and commercial fisheries and is considered a symbol of Canadian heritage and ecological health (Scott and Crossman 1973; COSEWIC 2010). Therefore, the first objective here is to use known ecological information about Atlantic salmon, along with observed and predicted responses of this species to climate warming, to discuss its potential for dispersal and establishment in the Canadian Arctic. The second objective is to investigate the possibility for interaction between anadromous Atlantic salmon and Arctic char in Canadian Arctic fresh waters, considering the ecology and current distributions of both species.

\section{Methods}

A comprehensive literature review was conducted to find information on thermal tolerances of Atlantic salmon and Arctic char across major stages of their life histories, specifically in fresh water. Both incipient lethal temperature (temperature that can be tolerated for a long period but not indefinitely) and ultimate lethal temperature (temperature that cannot be tolerated even for short periods) (Elliott and Elliott 2010) were found for both Atlantic salmon and Arctic char where possible. A further search was conducted for the general freshwater habitat requirements of Atlantic salmon and Arctic char across different life stages with a focus on abiotic parameters. This habitat information was summarized separately for European and North American Atlantic salmon populations, as well as for those that occur in "frontier" areas such as Greenland, Ungava Bay, and northern Iceland, in order to assess the colonization potential of Atlantic salmon to the Canadian Arctic based on area of origin. Habitat information for Arctic char was summarized separately for European and North American populations to contextualize data from sympatric European populations while highlighting differences between American and European populations, ultimately providing a more complete review. The distribution of 
both species and data on existing sympatric populations where they overlap was also identified from published records. The occurrence of vagrant Atlantic salmon outside known distribution was identified from Nunavut community harvest data (Government of Nunavut 2009, 2010, 2012a, b, 2013, 2014, 2015a, b, unpublished data) and a traditional ecological knowledge (TEK) study of Qikiqtarjuaq fishing areas (Janjua et al. 2016).

All literature review was conducted using the University of Manitoba library database, Web of Science, and Google Scholar. Articles were collected through searching important keywords as well as identifying relevant references from the articles located in this search. Primary keywords were "Atlantic salmon", "Salmo salar", "Arctic char", and "Salvelinus alpinus", paired with one or several of the following terms: "adult”, “juvenile”, “egg”, "spawning", and other life stage terms; "temperature", "thermal tolerance", "thermal limits", and other temperature-related derivatives; "lake habitat", "river habitat", "freshwater habitat" as well as specific habitat parameters including "depth" and "water velocity"; "distribution" and "range"; "sympatry" and "sympatric populations"; "Greenland", "Kapisillit", "Iceland", and "Ungava Bay". Papers were first screened for broad relevance using information presented in the abstract, then the contents of each paper were closely assessed for relevance to the objectives of this review.

\section{Results}

There is distributional overlap of Atlantic salmon and Arctic char in both North America and in Europe, and sympatric populations are known in Iceland, Norway, Russia, and in Ungava Bay (Grønvik and Klemetsen 1987; Salonius 1973). Atlantic salmon and Arctic char are similar in several aspects of their ecology and distribution, suggesting the potential for interaction between these species if Atlantic salmon were to shift northward into Arctic char habitats. Both species have similarly low temperature tolerances at all life stages (Table 1) and can survive and grow under ice cover (Klemetsen et al. 2003b; Linnansaari and Cunjak 2010). Riverine and lacustrine habitats may be used by both Atlantic salmon and Arctic char for spawning and rearing, potentially facilitating interaction in both habitats at multiple life stages. Their freshwater diets are also similar, as both species are considered generalist carnivores that prey on invertebrates and fish (Scott and Crossman 1973; Johnson 1980). The above similarities are enhanced by the great overlap in freshwater life cycles of Canadian Arctic char and Atlantic salmon, as both species hatch in spring, rear in fresh water for one or several years before migrating to the ocean, and return to spawn in fresh water in autumn (Scott and Crossman 1973; Johnson 1980).

\section{Distribution}

Arctic char have a circumpolar distribution and can be found as both freshwater resident and anadromous forms in northern hemispheric lakes and rivers, with lake use prevailing in the Arctic (Power and Reist 2018). The Arctic char is the northernmost freshwater fish (Klemetsen et al. 2003a) and occurs naturally in 16 countries (Fig. 1), with southern stocks confined to fresh water (Maitland 1995). In Canadian fresh waters, Arctic char populations occur from Newfoundland, Labrador and eastern Quebec, north to Hudson Bay and the Arctic Archipelago, and west to the Mackenzie River estuary (Power and Reist 2018). Anadromy is more prevalent in Greenland and Canadian Arctic stocks than those in the European Arctic; Norway has fewer anadromous stocks than Canada despite having ten times as many total populations, and Sweden has no migratory populations at all (Maitland 1995).

Atlantic salmon occur in rivers and lakes on both the east and west coasts of the North Atlantic Ocean in anadromous and freshwater resident populations, including a single, disjunct population in Kapisillit River, Greenland (Fig. 1) (MacCrimmon and Gots 1979; Thorstad et al. 2011). Spawning has sporadically been recorded in other Greenland rivers but the resulting progeny likely do not survive, given that these spawning fish are considered exceptional strays (Nielsen 1961; Jensen 1990). Many populations exist on the Arctic coasts of Norway and Russia, with the northernmost spawning populations found at $70^{\circ} \mathrm{N}$ in Finnmark County, Norway (MacCrimmon and Gots 1979; Kazakov and Veselov 1998; Nielsen et al. 2013). To date, however, no known Arctic populations of Atlantic salmon occur in North America, with the northernmost Canadian spawning populations occurring in sub-Arctic rivers draining into Ungava Bay (Lee and Power 1976). The Nastapoka River in the 
Table 1 Critical temperatures for survival at different life stages of Arctic char and Atlantic salmon

\begin{tabular}{|c|c|c|c|c|c|c|c|c|}
\hline \multirow[t]{2}{*}{ Life stage } & \multicolumn{4}{|c|}{ Arctic char (Salvelinus alpinus) } & \multicolumn{4}{|c|}{ Atlantic salmon (Salmo salar) } \\
\hline & Lower & References & Upper & References & Lower & References & Upper & References \\
\hline Eggs & $0{ }^{\circ} \mathrm{C}$ & $\begin{array}{l}\text { Elliott and } \\
\text { Baroudy } \\
(1995)^{\mathrm{c}}\end{array}$ & $8^{\circ} \mathrm{C}$ & $\begin{array}{l}\text { Elliott and } \\
\text { Baroudy } \\
(1995)^{\mathrm{c}}\end{array}$ & $0.15^{\circ} \mathrm{C}$ & $\begin{array}{l}\text { Wallace and } \\
\text { Heggberget } \\
(1988)^{\mathrm{a}, \mathrm{d}}\end{array}$ & $16^{\circ} \mathrm{C}$ & $\begin{array}{l}\text { Elliott and } \\
\text { Baroudy } \\
(1995)^{\mathrm{c}}\end{array}$ \\
\hline \multicolumn{9}{|l|}{ Juveniles } \\
\hline \multicolumn{9}{|l|}{ Alevins } \\
\hline Incipient & $0^{\circ} \mathrm{C}$ & $\begin{array}{l}\text { Elliott and } \\
\text { Elliott }(2010)^{\mathrm{c}}\end{array}$ & $19-21{ }^{\circ} \mathrm{C}$ & $\begin{array}{l}\text { Elliott and } \\
\text { Klemetsen } \\
(2002)^{\mathrm{a}, \mathrm{d}}\end{array}$ & $0{ }^{\circ} \mathrm{C}$ & $\begin{array}{l}\text { Elliott and } \\
\text { Elliott }(2010)^{\mathrm{c}}\end{array}$ & $23-24{ }^{\circ} \mathrm{C}$ & $\begin{array}{l}\text { Elliott and } \\
\text { Elliott } \\
(2010)^{\mathrm{c}}\end{array}$ \\
\hline Ultimate & $0{ }^{\circ} \mathrm{C}$ & $\begin{array}{l}\text { Elliott and } \\
\text { Elliott }(2010)^{\mathrm{c}}\end{array}$ & $23-26^{\circ} \mathrm{C}$ & $\begin{array}{l}\text { Elliott and } \\
\text { Klemetsen } \\
(2002)^{\mathrm{a}, \mathrm{d}}\end{array}$ & $0{ }^{\circ} \mathrm{C}$ & $\begin{array}{l}\text { Elliott and } \\
\text { Elliott }(2010)^{\mathrm{c}}\end{array}$ & $24-25^{\circ} \mathrm{C}$ & $\begin{array}{l}\text { Elliott and } \\
\text { Elliott } \\
(2010)^{\mathrm{c}}\end{array}$ \\
\hline \multicolumn{9}{|l|}{ Parr } \\
\hline Incipient & $0^{\circ} \mathrm{C}$ & $\begin{array}{l}\text { Elliott and } \\
\text { Baroudy } \\
(1995)^{\mathrm{c}}\end{array}$ & $21.6^{\circ} \mathrm{C}$ & $\begin{array}{l}\text { Baroudy and } \\
\text { Elliott } \\
(1994)^{\mathrm{a}, \mathrm{e}}\end{array}$ & $0^{\circ} \mathrm{C}$ & Elliott $(1991)^{\mathrm{a}, \mathrm{e}}$ & $27.8^{\circ} \mathrm{C}$ & $\begin{array}{l}\text { Elliott } \\
\qquad(1991)^{\mathrm{a}}\end{array}$ \\
\hline Ultimate & $-1{ }^{\circ} \mathrm{C}$ & $\begin{array}{l}\text { Elliott and } \\
\text { Elliott }(2010)^{\mathrm{c}}\end{array}$ & $26.6^{\circ} \mathrm{C}$ & $\begin{array}{l}\text { Baroudy and } \\
\text { Elliott } \\
(1994)^{\mathrm{a}, \mathrm{e}}\end{array}$ & $<0{ }^{\circ} \mathrm{C}$ & Elliott $(1991)^{\mathrm{a}, \mathrm{e}}$ & $33{ }^{\circ} \mathrm{C}$ & $\begin{array}{c}\text { Elliott and } \\
\text { Baroudy } \\
(1995)^{\mathrm{c}}\end{array}$ \\
\hline Adults & $<1{ }^{\circ} \mathrm{C}$ & $\begin{array}{l}\text { Amundsen and } \\
\text { Knudsen } \\
(2009)^{\mathrm{b}, \mathrm{d}}\end{array}$ & N/A & & N/A & & $29.5-30.5^{\circ} \mathrm{C}$ & $\begin{array}{l}\text { Huntsman } \\
(1942)^{b, f}\end{array}$ \\
\hline
\end{tabular}

${ }^{\mathrm{a}}$ Experimental study

${ }^{\mathrm{b} O b s e r v a t i o n a l ~ s t u d y ~}$

${ }^{\mathrm{c}}$ Information synthesis

${ }^{\mathrm{d}}$ Norway

${ }^{\mathrm{e}} \mathrm{UK}$

${ }^{\mathrm{f}}$ Nova Scotia

Hudson Bay hosts both a resident and an anadromous population of Atlantic salmon, likely colonized through headwater exchange with the Koksoak River in Ungava Bay (Morin 1991). It is suggested that the northern Newfoundland and Labrador coastline is a barrier to northward range expansion of Atlantic salmon in North America, due to a lack of suitable thermal habitat in fresh water for juvenile development (Salonius 1973; Nielsen et al. 2013).

Sympatric populations of anadromous Atlantic salmon and Arctic char exist in lakes and rivers in Iceland, northern Norway, and the Kola Peninsula in Russia (Grønvik and Klemetsen 1987; Heggenes and Saltveit 2007). Northern Canadian spawning populations of anadromous Arctic char and Atlantic salmon are only known to exist in sympatry in rivers of Ungava Bay and the Nastapoka River (Dunbar and
Hildebrand 1952; Salonius 1973; Coppinger and Ryan 1999). Dunbar and Hildebrand (1952) determined that Arctic char populations occur in all suitable lakes and rivers of Ungava Bay, whereas Atlantic salmon only utilize the larger rivers between the George River and the Koksoak River. Jessop et al. (1970) concluded that the Leaf River is the only river in Ungava Bay ascended by a substantial number of both Atlantic salmon and Arctic char.

\section{Nunavut harvest}

A TEK survey conducted in 2014 in Qikiqtarjuaq fishing areas revealed that more Atlantic salmon are being seen in those areas as compared to the past, particularly since the last TEK survey conducted in 1995/1997 (Read 2000; Janjua et al. 2016). Small 


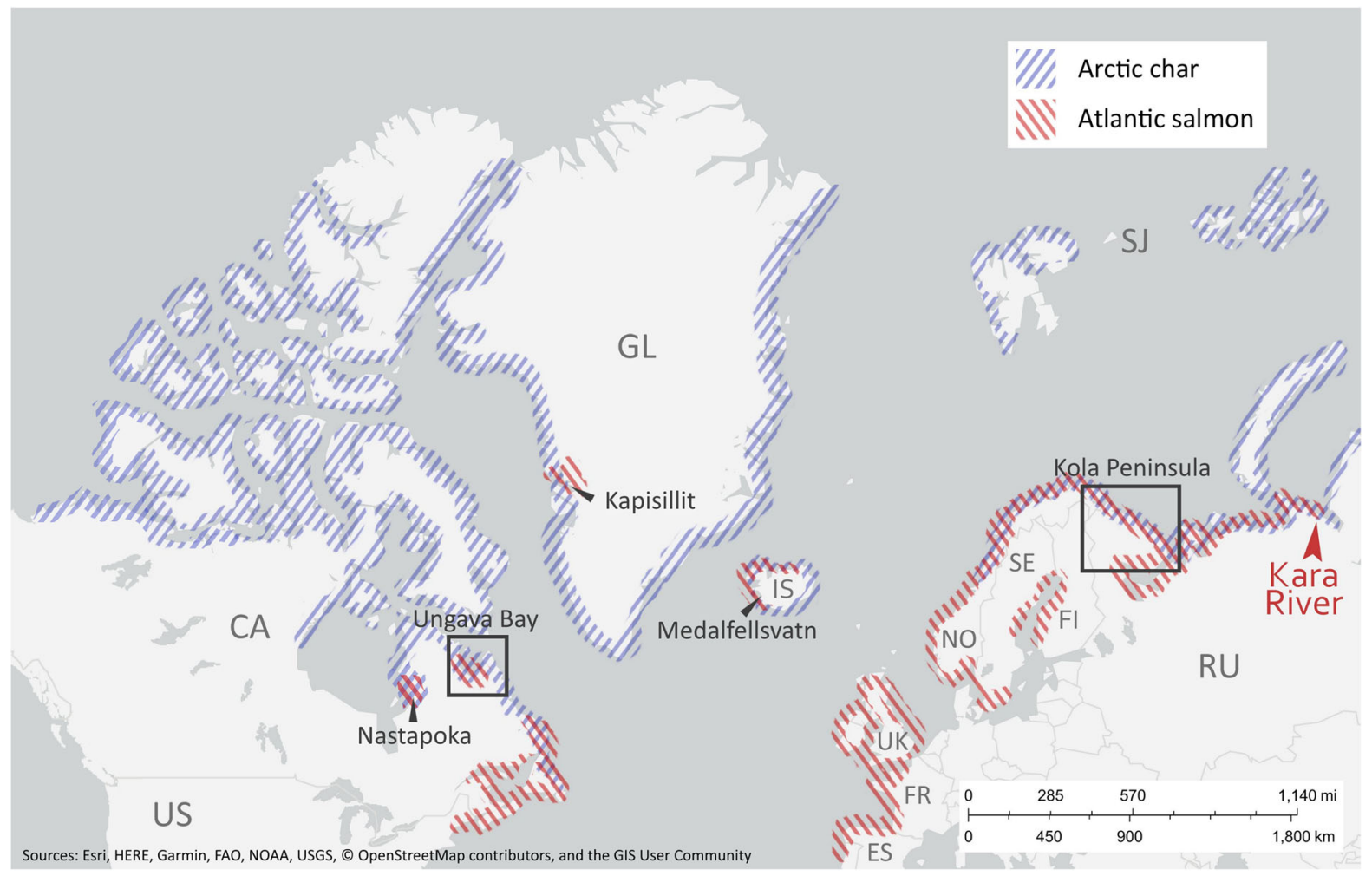

Fig. 1 Distribution of anadromous Atlantic salmon and Arctic char throughout the North Atlantic and Arctic Oceans, highlighting the Kara River (northeastern spawning limit of Atlantic salmon) and other locations mentioned in the text
(MacCrimmon and Gots 1979; Johnson 1980; Morin 1991; Jørgensen and Johnsen 2014; Power and Reist 2018). Countries labelled with ISO 3166-1 alpha-2 codes numbers of unknown or unusual fish, identified by harvesters as Atlantic salmon, have been reported in Canadian Arctic waters (Government of Nunavut 2009, 2010, 2012a, b, 2013, 2014, 2015a, b, unpublished data). Species identification of these unusual fishes was performed using photos provided by interviewers (Government of Nunavut 2012a), drawing on the ability of experienced harvesters to identify novel or uncommon fishes. The greatest number of these sightings have been in rivers and coastal waters near the Clyde River community (Fig. 2), primarily from August through October, though there were at least two recorded instances of Atlantic salmon in fresh waters during winter (Government of Nunavut 2014). Sightings in several lakes near Coral Harbour (Fig. 2) are apparently rare but have been reported by at least four hunters (Government of Nunavut 2012a).
Atlantic salmon have been seen migrating up the Kellett River near Kugaaruk in fall, where they are described as difficult to catch due to the strength of the running river (Government of Nunavut 2015b). Sightings are not exclusive to recent years; fish identified as Atlantic salmon have been seen in large numbers near Pond Inlet since the 1950s (Government of Nunavut unpublished data), one Atlantic salmon was caught in a river near Pangnirtung in 1998 (Government of Nunavut 2013), and one hunter caught an Atlantic salmon in the coastal waters of Cambridge Bay in 1992 (Government of Nunavut 2015a). Other locations with reported sightings or harvests of Atlantic salmon include coastal waters near Iqaluit, river nets in Kimmirut, the mouth of a river near Kugluktuk, coastal waters near Cape Dorset, and the coastal waters near Resolute Bay (including one large, 


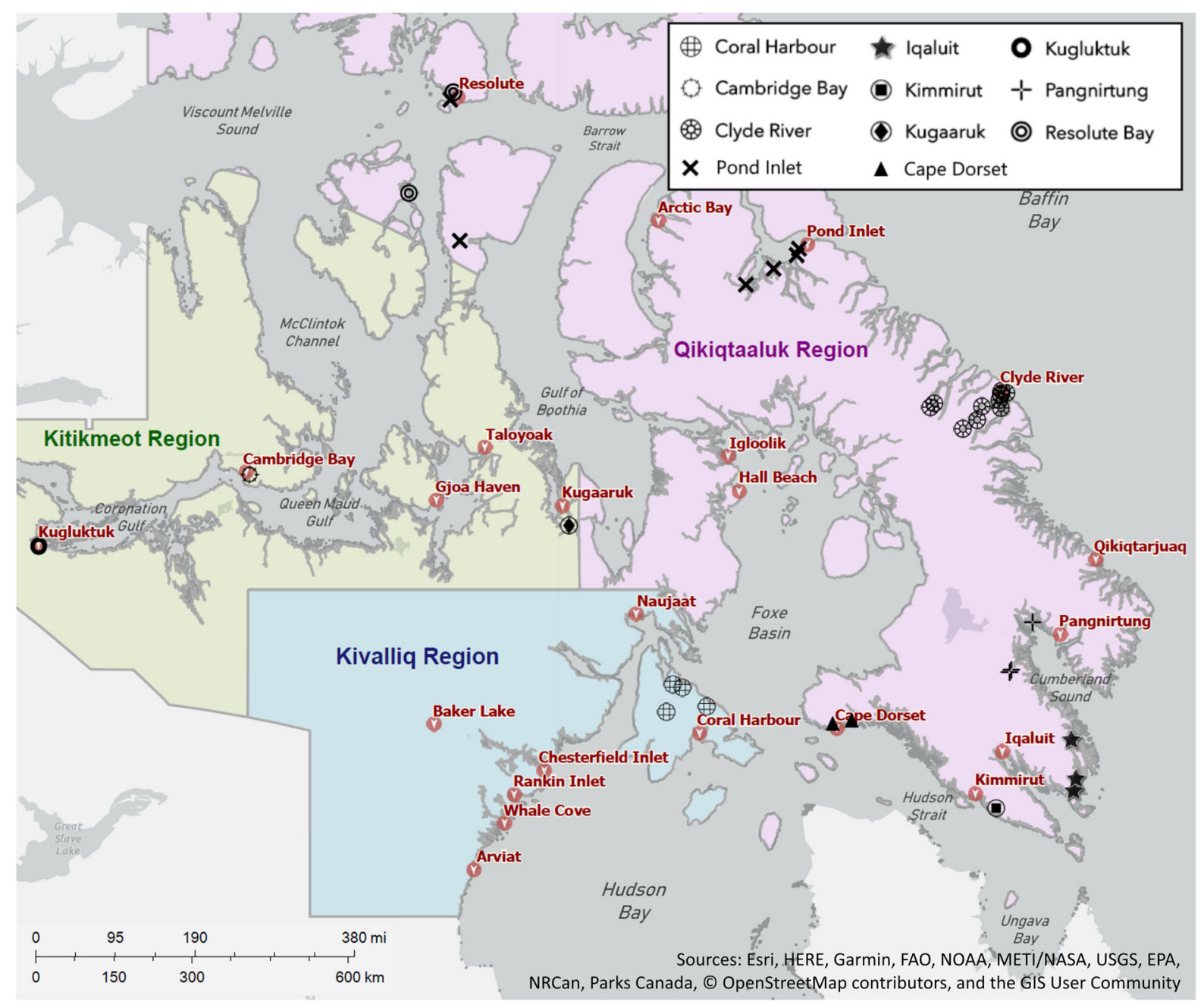

Fig. 2 Catch and sighting locations of fish identified as Atlantic salmon in Nunavut (data collected from: Government of Nunavut 2009, 2010, 2012a, b, 2013, 2014, 2015a, b, unpublished data)

unknown salmon) (Fig. 2) (Government of Nunavut 2009, 2010, 2012b, unpublished data). Communities with no reported Atlantic salmon harvests or sightings include Arctic Bay, Arviat, Baker Lake, Chesterfield Inlet, Gjoa Haven, Grise Fiord, Hall Beach, Iglulik, Naujaat, Rankin Inlet, Sanikiluaq, Taloyoak, and Whale Cove.

\section{Temperature}

Most thermal tolerance data for both Arctic char and Atlantic salmon are from European populations, with very few data from North American populations and virtually none from the cold-adapted Atlantic salmon populations. Atlantic salmon and Arctic char show overlap in lower thermal tolerances but Atlantic salmon appear to have a higher upper thermal limit than Arctic char (Table 1). Atlantic salmon can tolerate a greater range of temperatures across all life stages, from 0 to $33{ }^{\circ} \mathrm{C}$ (Table 1). Eggs may experience incubation temperatures of 0.1 to $0.3{ }^{\circ} \mathrm{C}$ in naturally occurring populations (Nielsen 1961; Wallace and Heggberget 1988). Juveniles are known to survive temperatures of $0{ }^{\circ} \mathrm{C}$ in the lab (Elliott 1991) and appear capable of acclimatizing to ice cover and winter temperatures near or below $0{ }^{\circ} \mathrm{C}$ while maintaining survival and growth (Cunjak 1988; Bremset 2000; Finstad et al. 2004; Linnansaari and Cunjak 2010). There is no evidence of thermal adaptation for eggs or juveniles, except possibly in very cold rivers 
(Wallace and Heggberget 1988; Elliott and Elliott 2010). However, there is a general lack of data pertaining to incubation temperatures in spawning habitats for Atlantic salmon and Arctic char. The thermal tolerances of adult Atlantic salmon in fresh water are less well understood than are those of the egg and juvenile stages, particularly at the lower critical temperature (Table 1) (DFO 2012). Seawater-acclimated adults can survive temperatures down to $-0.75{ }^{\circ} \mathrm{C}$ in the presence of ice (Fletcher et al. 1988), however, and temperature tolerance is sizespecific, meaning that larger individuals have lower thermal limits (DFO 2012). Adult Atlantic salmon likely have lower values of both upper and lower critical temperatures than do juvenile Atlantic salmon (DFO 2012). Compared to Atlantic salmon, Arctic char have a slightly narrower range of tolerated temperatures across all life stages, from 0 up to $26{ }^{\circ} \mathrm{C}$ (Table 1). The upper thermal limit of adult Arctic char is not well known (Table 1); however, like Atlantic salmon, it is likely lower than that of juveniles due to the relationship between size and thermal tolerances (DFO 2012). Like the Atlantic salmon, there is no evidence for geographic variation in thermal adaptation in Arctic chars (Elliott and Klemetsen 2002). For both species, the egg stage has the most limited range of tolerated temperatures, whereas the parr stage has the broadest range of tolerated temperatures (Table 1).

Habitat

Arctic char and Atlantic salmon are capable of both riverine and lacustrine spawning but show differences in spawning site preference (Table 2, 3). Riverine spawning sites of Arctic char have been documented over a wide range of depths, from less than $1 \mathrm{~m}$ in Russia, up to $11 \mathrm{~m}$ in northern Canada (Table 2). This variability can occur even within the same watershed, such as in the Cumberland Sound area of Baffin Island (Moore 1975). Spawning occurs in flows of 20-80 $\mathrm{cm} \mathrm{s}^{-1}$ or in stillwater pools (Harwood and Babaluk 2014) over a variety of spawning substrates from coarse sand to boulders and gravel (Table 2). Conversely, Atlantic salmon prefer to spawn in shallow (mean \pm standard deviation (SD); $0.45 \mathrm{~m} \pm 0.16 \mathrm{~m}$ ) areas of the main river and larger tributaries (Mills 1989; Louhi et al. 2008), in flows of $56 \mathrm{~cm} \mathrm{~s}^{-1} \pm 22 \mathrm{~cm} \mathrm{~s}^{-1}$ and over gravel from 1 to
$11.5 \mathrm{~cm}$ in diameter (Table 3). In northern lakes, Arctic char may spawn at depths from $0.5 \mathrm{~m}$ in Arctic Canada (Richardson et al. 2001) up to $100 \mathrm{~m}$ in Lake Blåsjön, Sweden (Johnson 1980), over cobble and gravel (Table 2). Little is known about Atlantic salmon spawning in lakes (Einarsson et al. 1990), but redds and eggs have been observed near outlet areas at $1-1.5 \mathrm{~m}$ depth in varied water flows, between crevices of rocks and boulders (Table 3). Spawning may also occur in the upwelling areas close to shore, such as in Lake Medalfellsvatn, Iceland (Einarsson et al. 1990).

Freshwater rearing preferences are well-documented for both Arctic char and Atlantic salmon juveniles (Table 2, 3). In rivers, Arctic char juveniles utilize stillwater pools or lower velocity water $\left(0-15 \mathrm{~cm} \mathrm{~s}^{-1}\right.$ in Europe; $1-30 \mathrm{~cm} \mathrm{~s}^{-1}$ in North America) and show a preference for substrate composed of gravel and varying sizes of stones (Johnson 1980) (Table 2). Arctic char juveniles have been described as using shallow stream waters both in allopatry (reviewed in Johnson 1980) and sympatry with Atlantic salmon, where they have been found in waters less than $10 \mathrm{~cm}$ deep (Heggberget 1984). Utilization of deeper waters $(60 \mathrm{~cm})$ may also occur (Table 2). Atlantic salmon juveniles prefer faster water velocities $\left(10-80 \mathrm{~cm} \mathrm{~s}^{-1}\right)$, coarser substrate such as boulders rather than gravel or sand (Holierhoek and Power 1995), and water depths up to $65 \mathrm{~cm}$, though juveniles in northern populations may be found up to $88 \mathrm{~cm}$ deep (Table 3). In Arctic lakes, juvenile Arctic char show a preference for the littoral zone, whereas in temperate lakes they typically use deeper water (Table 2). Juvenile lacustrine Arctic char are typically found over and within rocky bottoms, though exceptions do occur (Johnson 1980). Juvenile Atlantic salmon are also known to use the littoral zone of lakes (Table 3) and will use both macrophytic vegetation and rocks for shelter (Halvorsen and Jørgensen 1996).

Less information is available on the preferred freshwater habitats of adults of both Arctic char and Atlantic salmon. Riverine adult Arctic char tend to use deeper water than do juvenile conspecifics (Table 2) and are known to overwinter in deep pools of the main river, but most Canadian stocks of Arctic char overwinter in lakes (Harwood and Babaluk 2014). Adult Atlantic salmon migrating upriver for spawning occasionally rest in pools over $90 \mathrm{~cm}$ depth (Table 3 ) and are more bottom-oriented during the day 
Table 2 Habitat requirements across life stages of Arctic char

\begin{tabular}{|c|c|c|c|c|c|c|c|c|}
\hline \multirow{2}{*}{ Continent } & \multicolumn{4}{|c|}{ Riverine spawning requirements } & \multicolumn{4}{|c|}{ Lacustrine spawning requirements } \\
\hline & Depth & Water flow & Substrate & Reference & Depth & Water flow & Substrate & Reference \\
\hline $\begin{array}{l}\text { Europe and } \\
\text { Russia }\end{array}$ & $0.2-1.0 \mathrm{~m}$ & $20-80 \mathrm{~cm} \cdot \mathrm{s}^{-1}$ & $\begin{array}{l}\text { Fine or medium } \\
\text { pebbles }\end{array}$ & Volobuev $1973^{a}$ & $1-120 m$ & N/A & $\begin{array}{l}1-5 \mathrm{~cm} \\
\text { gravel }\end{array}$ & $\begin{array}{c}\text { Johnson } \\
1980^{b} ; R_{\text {Rubin }} \\
2005^{c}\end{array}$ \\
\hline \multirow[t]{3}{*}{$\begin{array}{l}\text { North } \\
\text { America }\end{array}$} & $<1-11 m$ & $20-70 \mathrm{~cm} \cdot \mathrm{s}^{-1}$ & $\begin{array}{c}\text { Coarse sand to } \\
\text { boulder strewn } \\
\text { gravel }\end{array}$ & $\begin{array}{l}\text { Harwood and } \\
\text { Babaluk } 2014^{d} \text {; } \\
\text { Moore } 1975^{d}\end{array}$ & $0.5-6 \mathrm{~m}$ & N/A & $\begin{array}{l}\text { Cobble and } \\
\text { gravel }\end{array}$ & $\begin{array}{c}\text { Richardson et } \\
\text { al. } 2001^{d}\end{array}$ \\
\hline & \multicolumn{4}{|c|}{ Riverine rearing requirements } & \multicolumn{4}{|c|}{ Lacustrine rearing requirements } \\
\hline & Depth & Reference & Water flow & Reference & & sition & Refe & rence \\
\hline $\begin{array}{l}\text { Europe and } \\
\text { Russia }\end{array}$ & $18-60 \mathrm{~cm}$ & $\begin{array}{c}\text { Gunnarsson and } \\
\text { Steingrimsson } \\
2011^{b}\end{array}$ & $0-15 \mathrm{~cm} \cdot \mathrm{s}^{-1}$ & $\begin{array}{c}\text { Gunnarsson and } \\
\text { Steingrimsson } \\
2011^{b}\end{array}$ & $\begin{array}{l}\text { Littoral } \\
\text { water }\end{array}$ & $\begin{array}{l}\text { emctic); deep } \\
\text { emperate) }\end{array}$ & Johnsc & $n 1980^{f}$ \\
\hline \multirow[t]{3}{*}{$\begin{array}{l}\text { North } \\
\text { America }\end{array}$} & Shallow water & Johnson $1980^{f}$ & $1-30 \mathrm{~cm} \cdot \mathrm{s}^{-1}$ & $\begin{array}{l}\text { Sinnatamby et al. } \\
2012^{d}\end{array}$ & $\begin{array}{l}\text { Littoral } \\
\text { water }\end{array}$ & $\begin{array}{l}\text { irctic); deep } \\
\text { emperate) }\end{array}$ & Johnsc & $\ln 1980^{f}$ \\
\hline & \multicolumn{4}{|c|}{ Riverine adult requirements } & \multicolumn{4}{|c|}{ Lacustrine adult requirements } \\
\hline & Depth & Reference & Water flow & Reference & & sition & Refe & rence \\
\hline $\begin{array}{l}\text { Europe and } \\
\text { Russia }\end{array}$ & Deeper water & Johnson $1980^{f}$ & $\mathrm{~N} / \mathrm{A}$ & & $\begin{array}{r}\text { Littoral, } \\
p\end{array}$ & $\begin{array}{l}\text { sometimes } \\
\text { lagic }\end{array}$ & Langeland & et al. $1991^{b}$ \\
\hline $\begin{array}{l}\text { North } \\
\text { America }\end{array}$ & Deeper water & Johnson $1980^{f}$ & $50-100 \mathrm{~cm} \cdot \mathrm{s}^{-1}$ & $\begin{array}{c}\text { Beddow et al. } \\
1998^{e}\end{array}$ & & N/A & & \\
\hline
\end{tabular}

${ }^{a}$ Eastern Russia (Salvelinus sp., species unclear)

${ }^{\mathrm{b}}$ Northern Europe

${ }^{\mathrm{c}}$ Western Europe

${ }^{\mathrm{d}}$ Northern Canada

${ }^{\text {e}}$ Eastern Canada

${ }^{\mathrm{f}}$ Information synthesis

(reviewed in Bardonnet and Baglinière 2000). Spawning migrations of adult Atlantic salmon are generally positively associated with increasing river flow, with exceptions related to migration stage and river-specific hydrological characteristics (Milner et al. 2012). Not much is known about the habitat use of the kelt stage of Atlantic salmon but they are known to use pools and backwaters in riverine environments (reviewed in Bardonnet and Baglinière 2000). In lakes, adult Arctic char primarily use the littoral zone in allopatry, though use of pelagic areas also occurs (Table 2). The habitat use of adult Atlantic salmon in lacustrine environments is not well-documented, though kelts may use lakes as habitat where available (Bardonnet and Baglinière 2000).

\section{Diet}

Both Atlantic salmon and Arctic char are opportunistic, generalist carnivores (Scott and Crossman 1973; Johnson 1980; Jørgensen et al. 2000). Arctic char eat a wide variety of vertebrates and invertebrates, with amphipods, insect larvae and fish being common prey items (reviewed in Scott and Crossman 1973). Where available, Arctic char selectively feed on larger organisms (Johnson 1980). Cannibalism on smaller conspecifics is common and occurs in many sympatric populations of resident and anadromous Arctic char (Klemetsen et al. 2003a; Svenning et al. 2007). Adult char have also been documented consuming Pacific salmon eggs (Volobuev 1973). Juvenile Atlantic salmon commonly feed on invertebrates, including insect larvae and adult insects, as well as small fish (Scott and Crossman 1973; Johansen et al. 2011). Piscivory by Atlantic salmon parr is thought to only occur in lacustrine rearing areas (Erkinaro et al. 1998). Anadromous adult Atlantic salmon typically do not feed during their freshwater migration, but occasional cannibalism by mature Atlantic salmon on parr and smolts has been recorded (Mills 1989). Landlocked adult Atlantic salmon are generally piscivorous if size allows, but dwarf adults are known to consume 
Table 3 Habitat requirements across life stages of Atlantic salmon

\begin{tabular}{|c|c|c|c|c|c|c|c|c|}
\hline \multirow{2}{*}{ Continent } & \multicolumn{4}{|c|}{ Riverine spawning requirements } & \multicolumn{4}{|c|}{ Lacustrine spawning requirements } \\
\hline & Depth & Water flow & Substrate & Reference & Depth & Water flow & Substrate & Reference \\
\hline Europe & $\begin{array}{c}0.45 \mathrm{~m} ; \mathrm{SD}= \\
0.16 \mathrm{~m}\end{array}$ & $\begin{array}{c}56 \mathrm{~cm} \cdot \mathrm{s}^{-1} ; \mathrm{SD}= \\
22 \mathrm{~cm} \cdot \mathrm{s}^{-1}\end{array}$ & $\begin{array}{l}11.5 \mathrm{~cm} ; \mathrm{SD}= \\
5.5 \mathrm{~cm} \text { gravel }\end{array}$ & $\begin{array}{l}\text { Heggberget et } \\
\text { al. } 1988^{a}\end{array}$ & $\mathrm{~N} / \mathrm{A}$ & $\begin{array}{l}\text { Upwelling } \\
\text { springs }\end{array}$ & N/A & $\begin{array}{c}\text { Einarsson et } \\
\text { al. } 1990^{a}\end{array}$ \\
\hline $\begin{array}{l}\text { North } \\
\text { America }\end{array}$ & $0.3-0.4 \mathrm{~m}$ & $55 \mathrm{~cm} \cdot \mathrm{s}^{-1}$ & $\leq 3 \mathrm{~cm}$ gravel & $\begin{array}{c}\text { Couturier et al. } \\
1986^{b}\end{array}$ & $1-1.5 \mathrm{~m}$ & Variable & $\begin{array}{l}1-30 \mathrm{~cm} \\
\text { rocks and } \\
\text { boulders }\end{array}$ & $\begin{array}{c}\text { Couturier et al. } \\
1986^{b}\end{array}$ \\
\hline \multirow[t]{3}{*}{$\begin{array}{l}\text { Cold- } \\
\text { adapted }\end{array}$} & $\mathrm{N} / \mathrm{A}$ & N/A & Gravel beds & $\begin{array}{c}\text { Arnekleiv et al. } \\
2019^{c}\end{array}$ & $\mathrm{~N} / \mathrm{A}$ & $\mathrm{N} / \mathrm{A}$ & N/A & \\
\hline & \multicolumn{4}{|c|}{ Riverine rearing requirements } & \multicolumn{4}{|c|}{ Lacustrine rearing requirements } \\
\hline & Depth & Reference & Water flow & Reference & & ition & $\operatorname{Re}$ & erence \\
\hline Europe & $15-65 \mathrm{~cm}$ & $\begin{array}{l}\text { Mäki-Petäys et } \\
\quad \text { al. } 2002^{a}\end{array}$ & $20-80 \mathrm{~cm} \cdot \mathrm{s}^{-1}$ & $\begin{array}{l}\text { Mäki-Petäys et } \\
\text { al. } 2002^{a}\end{array}$ & & toral & $\begin{array}{r}\text { Halvorsen } \\
1\end{array}$ & $\begin{array}{l}\text { nd Jørgensen } \\
96^{a}\end{array}$ \\
\hline $\begin{array}{l}\text { North } \\
\text { America }\end{array}$ & $6-54 \mathrm{~cm}$ & $\begin{array}{c}\text { Rimmer et al. } \\
1984^{b}\end{array}$ & $<10-50 \mathrm{~cm} \cdot \mathrm{s}^{-1}$ & $\begin{array}{c}\text { Rimmer et al. } \\
1984^{b}\end{array}$ & & $\mathrm{~J} / \mathrm{A}$ & & \\
\hline \multirow[t]{3}{*}{$\begin{array}{l}\text { Cold- } \\
\text { adapted }\end{array}$} & $10-88 \mathrm{~cm}$ & $\begin{array}{c}\text { Tunney and } \\
\text { Steingrimsson } \\
2012^{d}\end{array}$ & $2.3-65.7 \mathrm{~cm} \cdot \mathrm{s}^{-1}$ & $\begin{array}{c}\text { Tunney and } \\
\text { Steingrimsson } \\
2012^{d}\end{array}$ & Littoral (o & $\begin{array}{l}\text { ler areas not } \\
\text { hed) }\end{array}$ & Arnekleiv & et al. $2019^{c}$ \\
\hline & \multicolumn{4}{|c|}{ Riverine adult requirements } & \multicolumn{4}{|c|}{ Lacustrine adult requirements } \\
\hline & Depth & Reference & Water flow & Reference & & ition & $\operatorname{Ret}$ & rence \\
\hline Europe & $\begin{array}{l}>90 \mathrm{~cm} \text { (holding } \\
\text { pools) }\end{array}$ & $\begin{array}{l}\text { Bardonnet and } \\
\text { Baglinière } 2000^{e}\end{array}$ & $\mathrm{~N} / \mathrm{A}$ & & & $\mathrm{J} / \mathrm{A}$ & & \\
\hline $\begin{array}{l}\text { North } \\
\text { America }\end{array}$ & $\begin{array}{c}>90 \mathrm{~cm} \text { (holding } \\
\text { pools) }\end{array}$ & $\begin{array}{l}\text { Bardonnet and } \\
\text { Baglinière } 2000^{e}\end{array}$ & $\mathrm{~N} / \mathrm{A}$ & & & $\mathrm{V} / \mathrm{A}$ & & \\
\hline $\begin{array}{l}\text { Cold- } \\
\text { adapted }\end{array}$ & $\mathrm{N} / \mathrm{A}$ & & N/A & & & $\mathrm{J} / \mathrm{A}$ & & \\
\hline
\end{tabular}

${ }^{\mathrm{a}}$ Northern Europe

${ }^{\mathrm{b}}$ Eastern Canada

${ }^{\mathrm{c}}$ Greenland

${ }^{\mathrm{d}}$ Northern Iceland

${ }^{\mathrm{e}}$ Information synthesis

primarily zooplankton (reviewed in Johansen et al. 2011).

\section{Interaction}

Competition between Atlantic salmon and Arctic char is sometimes inferred (e.g. Halvorsen et al. 1997; Heggenes and Saltveit 2007) but literature review revealed no studies looking directly at competitive interactions or interspecies aggression at an individual level in the wild. Indeed, previous studies investigating interaction between Atlantic salmon and Arctic char often cannot fully separate the roles of selective segregation and interactive segregation in determining resource use (Heggenes and Saltveit 2007). Habitat and resource partitioning occurs between Atlantic salmon and Arctic char in both riverine and lacustrine habitats (Halvorsen et al. 1997; Jørgensen et al. 2000;
Heggenes and Saltveit 2007), though the presence of aggressive brown trout (Salmo trutta) in many of these study systems complicates definitive conclusions (Langeland et al. 1991). Habitat segregation observed in a sympatric Norwegian population of Atlantic salmon and Arctic char likely results from both species-specific and interactive selective forces, as well as rising freshwater temperatures (Svenning et al. 2016). Atlantic salmon are considered a more aggressive species than Arctic char, with a competitive advantage in faster-flowing waters, whereas Arctic char may be a better competitor in lakes (Halvorsen and Jørgensen 1996). Interestingly, Atlantic salmon and Arctic char in duoculture both show higher growth rates and lower intraspecific aggression than in monoculture (Holm 1989). Fish in aquaculture are held in much higher densities than typically found in 
the wild, however, so application of these results to wild populations is tenuous at best (Holm 1989).

\section{Life cycle}

The life cycles of Arctic char and Atlantic salmon share many similarities, particularly in fresh water (Fig. 3). In Canada, the anadromous forms of both species spawn in autumn, with eggs hatching in spring and alevins emerging in summer (Fig. 3) (Scott and Crossman 1973; Johnson 1980; Thorstad et al. 2011). Arctic char in more southern habitats tend to spawn in later months (Scott and Crossman 1973). Given that incubation duration for both species depends on temperature, with warmer temperatures leading to shorter incubation times (Scott and Crossman 1973; Jeuthe et al. 2016), southern Arctic char populations that spawn in later months could hatch at similar times to more northern Arctic char. Both species are capable of spawning in rivers and lakes, though sympatric populations of Atlantic salmon and Arctic char show a tendency for Atlantic salmon to spawn in rivers and stream beds, while Arctic char generally spawn in lakes (Jørgensen et al. 2000; Jensen et al. 2012). Juveniles of both Arctic char and Atlantic salmon spend several years rearing in fresh water, feeding and growing until they are large enough to smoltify and make their seaward migration (Fig. 3) (Scott and Crossman 1973). Once in the ocean, Atlantic salmon typically make long-distance migrations lasting from one to several years, though estuarine forms of Atlantic salmon are known in Ungava Bay and the Nastapoka River (Robitaille et al. 1986; Morin 1991). Arctic char remain coastal during ocean migration and typically return to fresh water to overwinter (Fig. 3), though some Arctic char remain in fresh water the year before spawning rather than returning to the ocean (Harwood and Babaluk 2014). At maturity, individuals of both species return to their natal streams for spawning; as both species are iteroparous (Johnson 1980; Thorstad et al. 2011), surviving postspawners will eventually return to the ocean (Fig. 3).

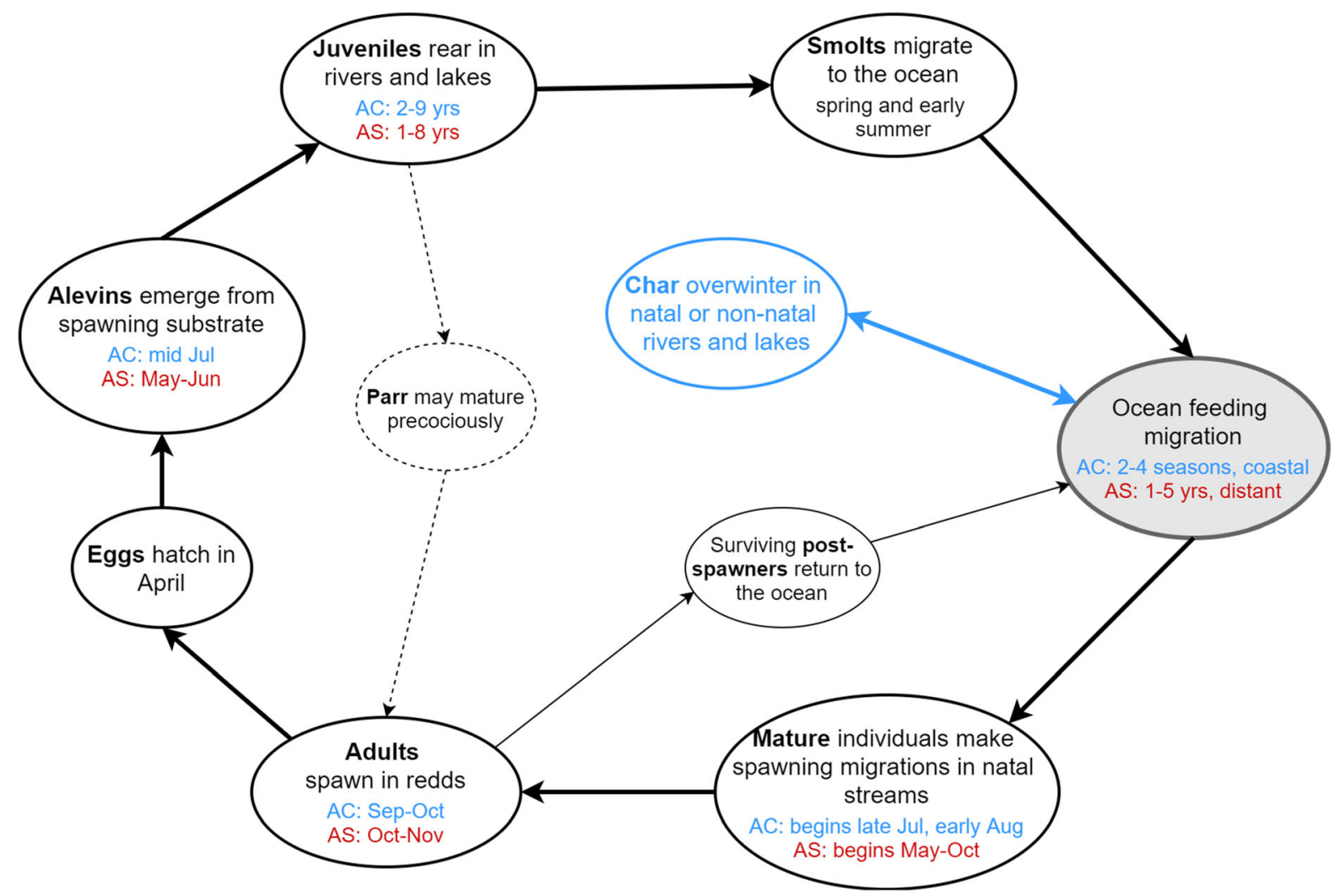

Fig. 3 Simplified life cycle of Canadian anadromous Arctic char (AC) and Atlantic salmon (AS) with a focus on freshwater life stages (Scott and Crossman 1973; Johnson 1980; Jonsson and Jonsson 2001; Thorstad et al. 2011) 


\section{Discussion}

Dispersal and establishment

Atlantic salmon are predicted to shift their distribution northward with changing thermal habitats (Jonsson and Jonsson 2009) and vagrant fish identified as Atlantic salmon have been harvested outside their known distribution in several lakes, rivers, and coastal areas in Nunavut (Government of Nunavut 2009, 2010, 2012a, b, 2013, 2014, 2015a, b, unpublished data). The overall lack of biological data in these reports, such as population of origin and maturation status, prevents understanding of the origin of these fish and whether they can establish spawning populations. Another potential issue with these reports is the possibility of misidentification. For example, the lone fish caught in Kugluktuk was identified as an Atlantic salmon (Government of Nunavut 2010) but could instead be a misidentified Pacific salmon, given the presence of Pacific salmon in this location (Dunmall et al. 2018) and the similarities between Pacific and Atlantic salmon (Fisheries and Oceans Canada 2018). Experienced harvesters know when they have caught an unusual fish, however, so we can be confident that the reported fish are not the typical species or phenotypes caught in these locations. While thought not yet to be established, the occurrence of fish identified as Atlantic salmon in these novel locations suggests that the species can access both marine and freshwater habitats outside their typical range. Access to new areas is likely a result of environmental change. As these locations are within the known distribution of Arctic char, and as there is also considerable overlap in life cycle and habitat preferences between these species, it is important to understand both the potential for colonization by Atlantic salmon in the Canadian Arctic, and the resulting interactions between native Arctic char and Atlantic salmon in these northern watersheds.

Dispersal of Atlantic salmon into the Canadian Arctic may be facilitated by the oceanography of Davis Strait and Baffin Bay, particularly the patterns of circulation. The West Greenland Current (WGC) transports water northward along the western coast of Greenland, while the Baffin Island Current (BIC) flows southward along the eastern coast of Baffin Island (Hamilton and Wu 2013). Atlantic salmon from both North American and European populations have used the waters off west Greenland as feeding grounds since at least as early as the 1930s (Jensen 1990) and could disperse into the Canadian Arctic following the WGC northward, including the cross currents to Baffin Island, and then the BIC southward. The higher abundance of Atlantic salmon catches in and around the Clyde River community (Government of Nunavut 2014) could be evidence of this conduit for Atlantic salmon to the Canadian Arctic, as Clyde River is directly along the path of the BIC (Hamilton and Wu 2013) and Atlantic salmon following this current could potentially reach Clyde River more easily than the other Nunavut communities.

Historical colonizations by Atlantic salmon followed retreating glaciers (King et al. 2001). North American populations were restricted to more southern habitats during the Pleistocene glaciations, thus could only recolonize northern watersheds as the Laurentide ice sheet retreated and those rivers and lakes returned to habitable temperatures (Power 1958). The current European and Russian distributions were likely colonized from multiple different postglacial routes (Nilsson et al. 2001; Makhrov et al. 2005). Atlantic salmon colonizing new habitats following glacial retreat would have faced fluctuating climatic conditions (Power 1958), but the adaptations of Ungava Bay Atlantic salmon to cold temperatures and a short growing season (Lee and Power 1976) demonstrate an ability to colonize rivers with harsh conditions. These postglacial colonizations likely occurred over hundreds or thousands of years (King et al. 2001), whereas contemporary colonizations by other salmonids occur over tens of years (Milner et al. 2007).

The importance of temperature in constraining the current range of Atlantic salmon (MacCrimmon and Gots 1979) will be a defining factor in potential colonizations. Narrow thermal tolerances at the egg stage appear to be a colonization bottleneck for Pacific salmon shifting northward (Dunmall et al. 2016); alternatively, the apparent tolerance by Atlantic salmon for cold temperatures even during egg development may be a key characteristic that could facilitate Atlantic salmon colonizing novel locations in the Canadian Arctic. Considering the overlap in thermal tolerances between Atlantic salmon and Arctic char, and the presence of suitable habitat for Arctic char in Canadian fresh waters, it is possible that suitable thermal habitat for Atlantic salmon at all 
Table 4 Summary of expected and possible changes and their implications for Arctic char and Atlantic salmon in the Canadian Arctic

\begin{tabular}{|c|c|c|}
\hline Changes & Potential implications & References \\
\hline \multirow[t]{4}{*}{$\begin{array}{l}\text { Warming freshwater } \\
\text { temperatures }\end{array}$} & $\begin{array}{l}\text { Suitability of Arctic fresh waters for Atlantic } \\
\text { salmon expected to increase }\end{array}$ & Reist et al. (2006a) \\
\hline & $\begin{array}{l}\text { Atlantic salmon may be more suited to warmer } \\
\text { fresh waters than Arctic char }\end{array}$ & Gilbert and Tierney (2018) \\
\hline & $\begin{array}{l}\text { Increase in productivity could lead to decrease in } \\
\text { Arctic char anadromy }\end{array}$ & Finstad and Hein (2012) \\
\hline & $\begin{array}{l}\text { Atlantic salmon could outcompete Arctic char in } \\
\text { certain rivers; could lead to a reduction or } \\
\text { exclusion of Arctic char from more southerly } \\
\text { habitat }\end{array}$ & $\begin{array}{l}\text { Jonsson et al. (2001), Larsson et al. (2005), } \\
\text { Reist et al. (2006a), Gilbert and Tierney } \\
\text { (2018) }\end{array}$ \\
\hline \multirow{3}{*}{$\begin{array}{l}\text { Vagrant Atlantic salmon } \\
\text { dispersing into the } \\
\text { Canadian Arctic }\end{array}$} & $\begin{array}{l}\text { Atlantic salmon may establish in watersheds } \\
\text { occupied by Arctic char }\end{array}$ & $\begin{array}{l}\text { Government of Nunavut } \\
(2009,2010,2012 a, b, 2013,2014,2015 a, b)\end{array}$ \\
\hline & $\begin{array}{l}\text { Atlantic salmon and Arctic char could live in } \\
\text { sympatry, with potential competition for } \\
\text { resources and habitat }\end{array}$ & $\begin{array}{l}\text { Grønvik and Klemetsen (1987), Heggenes and } \\
\text { Saltveit (2007) }\end{array}$ \\
\hline & $\begin{array}{l}\text { Could present an opportunity for an Atlantic } \\
\text { salmon fishery }\end{array}$ & Dunbar (1970), Kazakov and Veselov (1998) \\
\hline \multirow{4}{*}{$\begin{array}{l}\text { Atlantic salmon and Arctic } \\
\text { char living in sympatry in } \\
\text { the Canadian Arctic }\end{array}$} & $\begin{array}{l}\text { Potential competition for riverine and lacustrine } \\
\text { spawning habitat due to freezing of rivers }\end{array}$ & Power et al. (1999) \\
\hline & $\begin{array}{l}\text { Habitat segregation in rivers: Arctic char in slow- } \\
\text { flowing water near riverbanks, Atlantic salmon } \\
\text { in fast-flowing waters near midstream }\end{array}$ & $\begin{array}{l}\text { Heggberget (1984), Heggenes and Saltveit } \\
\text { (2007) }\end{array}$ \\
\hline & $\begin{array}{l}\text { Habitat segregation in lakes: Arctic char juveniles } \\
\text { restricted to pelagic until temperatures cool }\end{array}$ & $\begin{array}{l}\text { Halvorsen and Jørgensen (1996), O'Connell and } \\
\text { Dempson (1996), Jørgensen et al. (2000) }\end{array}$ \\
\hline & $\begin{array}{l}\text { Diet overlap and consumption of eggs/smaller } \\
\text { fishes by larger fish implies possible trophic } \\
\text { interactions }\end{array}$ & $\begin{array}{l}\text { Volobuev (1973), Mills (1989), Klemetsen et al. } \\
\text { (2003a) }\end{array}$ \\
\hline
\end{tabular}

freshwater life stages is currently available in the Canadian Arctic. For example, temperatures associated with anadromous Arctic char in two South Baffin Island lakes ranged from 0.3 to $10.9^{\circ} \mathrm{C}$ in fall and winter (Young 2019), similar to temperatures experienced by the Kapisillit Atlantic salmon in Greenland (Nielsen 1961; Hedeholm et al. 2018). As climate warming continues and freshwater temperatures rise, the suitability of northern habitats for Atlantic salmon is expected to increase (Table 4) (Schindler 2001; Reist et al. 2006a; IPCC 2014). Worth mentioning is that pure temperature tolerance data cannot necessarily be used to assess individual success, as water temperature within a species' thermal limits still influences energy budget and body condition in salmonids (Jonsson and Jonsson 2011; Gilbert and Tierney 2018). For example, water temperature impacts migratory ability and aerobic recovery in both Arctic char and Atlantic salmon (Moore et al. 2012; Gilbert and Tierney 2018), as well as habitat choice and interspecies interactions among salmonid juveniles (Mills 1989; Svenning et al. 2016). However, temperature tolerance at the thermally-vulnerable egg stage, a life stage critical for establishment, may be used as a proxy to broadly assess colonization potential (Adams and Maitland 2001; Dunmall et al. 2016). Thermal limits of juvenile and adult Atlantic salmon and Arctic char were summarized here for completeness but are less ecologically applicable when assessing colonization potential, though they indicate similarities between the two species that may allow them to exist in sympatry. Evidence suggests temperate salmonids may even be more physiologically suited to some Arctic rivers than native Arctic char as temperatures increase (Gilbert and Tierney 2018). The behavioural flexibility of Atlantic salmon 
in response to environmental conditions, as evidenced by the estuarine salmon in Ungava Bay and Nastapoka River (Robitaille et al. 1986; Morin 1991), could be especially important for success in cold Arctic environments.

Interaction between salmon and char

If Atlantic salmon colonize Canadian Arctic fresh waters, information about the extent of interaction among Atlantic salmon and Arctic char in areas where they already occur in sympatry may be used to predict potential competition (Table 4). Atlantic salmon and Arctic char overlap in spawning season (Scott and Crossman 1973) which could facilitate interaction at this life stage. Sympatric populations tend to show segregation in spawning habitat; Atlantic salmon preferentially spawn in rivers, whereas Arctic char spawn in lakes (Jørgensen et al. 2000; Jensen et al. 2012). The shallow spawning sites typically chosen by Atlantic salmon in rivers may freeze in the Canadian Arctic, however, and rivers in the Canadian Arctic often freeze completely in winter (Johnson 1980), limiting river-spawning to unfrozen sites of warm groundwater influx (Power et al. 1999). In these watersheds, spawning habitats for Atlantic salmon would be associated with these groundwater springs, and may be limiting (Power et al. 1999). Atlantic salmon may also adopt lake-spawning behaviour. This could facilitate interaction with anadromous lakespawning Arctic char and lake-resident Arctic char in ocean-accessible habitat (Table 4) (Salisbury et al. 2018), both of which may be used in subsistence fishing. The limited data on lake-spawning Atlantic salmon (Einarsson et al. 1990), as well as the lack of data on the spawning preferences of cold-adapted Atlantic salmon populations in Greenland, northern Iceland and Ungava Bay (Table 3), preclude conclusive predictions of the potential interactions between spawning Arctic char and Atlantic salmon in the Canadian Arctic.

Atlantic salmon and Arctic char also overlap in life cycle and broad-scale habitat use during the freshwater juvenile life stage and show resource partitioning in sympatry (Table 4). In rivers with sympatric populations, Arctic char juveniles are typically found in slow-flowing water near the riverbanks or in stillwater pools, whereas Atlantic salmon juveniles favour fastflowing areas closer to midstream (Table 4)
(Heggberget 1984; Heggenes and Saltveit 2007). This habitat partitioning likely arises from a combination of selective segregation and interspecific competition (Heggenes and Saltveit 2007; Svenning et al. 2016). These are data from European populations; however, the same patterns could occur in Canadian Arctic rivers containing Arctic char (e.g. the Cumberland Sound area; Moore 1975) if Atlantic salmon juveniles were to share these riverine rearing habitats. Few conclusions can be drawn about potential trophic competition in rivers as the diet overlap of juvenile Atlantic salmon and Arctic char occurring sympatrically in rivers is unknown. In sympatric lake populations, Atlantic salmon juveniles use the littoral zone, whereas Arctic char juveniles are primarily restricted to the pelagic and profundal zones during summer but use the littoral zone alongside Atlantic salmon as temperatures decrease in late autumn (Table 4) (Halvorsen and Jørgensen 1996; O'Connell and Dempson 1996; Jørgensen et al. 2000). This restriction of Arctic char from the littoral zone is speculated as the cause of diet partitioning between these two species documented in a northern Norwegian lake (Jørgensen et al. 2000). If anadromous Atlantic salmon do ultimately use lakes in the Canadian Arctic as rearing habitat, a strategy documented in both European (Halvorsen and Jørgensen 1996) and North American (O'Connell and Dempson 1996) populations, evidence suggests they could displace Arctic char juveniles to deeper waters in the warmer summer months (Halvorsen et al. 1997). This restriction would likely intensify as surface temperatures increase with climate change (Vincent et al. 2013).

A key data gap in understanding the potential interaction between Atlantic salmon and Arctic char is the lack of available data on the sympatric habitat selection of Arctic char and Atlantic salmon juveniles in the winter months. Winter is often considered a critical period for fish survival (Hurst 2007) and winters in the Canadian Arctic are extreme and last several months (Coates and Morrison 2001). Similar to Arctic char juveniles, riverine Atlantic salmon juveniles show a preference for deeper, slow-moving water and pools during winter (Mills 1989), but the effects of this potential overlap in habitat preference are unknown. Similarly, the winter habitat of Atlantic salmon juveniles in Arctic lakes is not well documented, therefore the potential for interaction among Atlantic salmon and Arctic char juveniles 
overwintering in lakes is also unknown. This is a key data gap given the length of winters and the potentially limited habitat availability for overwintering fishes in the Canadian Arctic.

Potential interactions between adult Atlantic salmon and Arctic char are much more difficult to estimate, owing to a lack of information on their freshwater habitat preferences. Atlantic salmon kelts may use freshwater habitat during winter for up to several months after spawning and seem to show a preference for pools and lakes, but little is known about this period (Bardonnet and Baglinière 2000), so potential interaction with overwintering Arctic char adults is unknown. There appears to be temporal overlap in spawning migrations of Canadian Atlantic salmon and Arctic char, but the consequences of potential interaction are difficult to estimate as no data are available on the dynamics of migrating Atlantic salmon and Arctic char in sympatric populations and the upstream migrations of many Arctic char populations are complex (Johnson 1980). Trophic competition between adult Atlantic salmon and Arctic char may be minimal, as anadromous adults of both species rarely feed during freshwater spawning migrations (Mills 1989). Facultative piscivory and cannibalization of juvenile conspecifics by both species (Mills 1989; Klemetsen et al. 2003a) could potentially extend to predation on juveniles of the other species, and the consumption of Pacific salmon eggs by adult char (Volobuev 1973) implies the possibility of adult Arctic char feeding on Atlantic salmon eggs (Table 4). Limited data on the kelt stage of Atlantic salmon (Bardonnet and Baglinière 2000) further precludes understanding of potential adult interaction in fresh water.

If and how these species will interact if Atlantic salmon expand northwards is essential information for both local subsistence fishers and small commercial fisheries, as any changes in the ecosystem will be relevant to inform the management of Arctic char stocks (Kristofferson and Berkes 2005). There may be a decrease in anadromy among Arctic char populations as freshwater temperatures and productivity increase (Table 4) (Finstad and Hein 2012), facilitating further potential interaction in fresh water, as well as potentially impacting subsistence fishing that primarily targets upstream migration (Kristofferson and Berkes 2005). This shift towards a lower proportion of anadromy will likely occur at population- specific rates, given that sympatric anadromous and resident populations can be differentiated both genetically (Salisbury et al. 2018) and as conditional phenotypes (Moore et al. 2014). Warming fresh waters could also lead to Atlantic salmon outcompeting Arctic char (Table 4), as Atlantic salmon and other temperate salmonids perform better and have higher aerobic capacity than Arctic char in warmer waters (Jonsson et al. 2001; Larsson et al. 2005; Gilbert and Tierney 2018). In this case, reduction or exclusion of Arctic char from more southerly habitats presently occupied may be expected (Reist et al. 2006a). Though some Arctic char populations can tolerate substantial exploitation (e.g., north Labrador; Dempson et al. 2008), reduced Arctic char populations may be unable to tolerate exploitation when coupled with expected environmental changes, which could be problematic for subsistence and commercial fisheries (Kristofferson and Berkes 2005). As the northernmost freshwater fish, Canadian Arctic char will be unable to expand their range northward. On the other hand, Atlantic salmon expanding north could present new opportunities for fisheries in the Canadian Arctic. A small, stable Atlantic salmon fishery exists on the Kola Peninsula on the Arctic coast of Russia (Kazakov and Veselov 1998), potentially implying the possibility of small commercial Atlantic salmon fisheries in the Canadian Arctic (Table 4). Conversely, the Ungava Bay commercial Atlantic salmon fishery that began in 1881 led to declines and was ultimately abandoned in the early 1930s due to disappointing output (Dunbar 1970). Considering the contrasting results of these two northern Atlantic salmon fisheries, the possibility of an Atlantic salmon fishery in the Canadian Arctic is uncertain.

\section{Next steps}

Filling data gaps is necessary to better understand the potential for Atlantic salmon to colonize Canadian Arctic habitats, and to assess the resulting interactions with native Arctic species. Temperature data for spawning, rearing, and overwintering habitats of Arctic char in northern Canada, and especially in association with perennial groundwater springs (Dunmall et al. 2016), are necessary for further consideration of possible Atlantic salmon establishment. Future experiments should better define the thermal limits of adult stages of Atlantic salmon and Arctic 
char, to better understand their thermal niches and make more robust statistical models of thermallysuitable freshwater habitats. The gaps identified in Table 1 are particularly important, as are studies investigating any differences between experimental and observed temperature tolerances. The lack of information about sympatric Atlantic salmon and Arctic char populations during the winter months, a critical period for fish survival (Hurst 2007), is especially important in the Canadian Arctic. Data on existing populations of Atlantic salmon and Arctic char in sympatry are limited; a search of the English literature found no studies on Icelandic or Russian populations, and populations in Ungava Bay have only been superficially assessed for competition (Salonius 1973). Further study on these Ungava Bay populations may offer unique insight into sympatry of Atlantic salmon and Arctic char in cold Canadian waters. Experimental and observational studies of the existence and extent of aggression and competition in sympatric populations is also needed for more thorough analysis of potential interaction in the Canadian Arctic.

The authors have identified a series of future research questions and considerations that serve to fill data gaps and improve understanding of Atlantic salmon and Arctic char within the context of colonization potential in the Canadian Arctic. These questions highlight a range of physiological, ecological, and sociological concerns, and are as follows:

1. What are the geographic origins of the vagrant Atlantic salmon being seen and harvested in Nunavut communities?

2. Are there northern Canadian watersheds with the right temperature, flow, and substrate conditions to support spawning populations of Atlantic salmon?

3. How prevalent are groundwater springs in the eastern Canadian Arctic? Where are these groundwater springs located?

4. Do temperature tolerances differ between European and North American stocks of Arctic char and Atlantic salmon?

5. How do the temperature tolerances of coldadapted Atlantic salmon (such as those from Greenland, northern Iceland, and Ungava Bay) differ from the rest of the species?
6. Do cold-adapted Atlantic salmon have different spawning preferences? Different freshwater rearing preferences?

7. What are the specific spawning preferences of lacustrine Atlantic salmon? What environmental factors lead to lacustrine spawning?

8. What are the freshwater habitat requirements of all adult stages of Atlantic salmon and Arctic char? To what extent is fresh water used during upstream and post-spawning migration?

9. How do the sympatric populations of Arctic char and Atlantic salmon in the rivers of Ungava Bay co-exist and interact? Do they experience resource partitioning?

10. To what extent is resource partitioning between these two species in sympatry due to competitive interactions?

11. What are Indigenous perspectives on a potentially increasing incidence of Atlantic salmon in the Arctic? What are the social and cultural consequences and opportunities of such a shift?

Further research using the above questions as a guideline will be necessary to better assess the effects of Atlantic salmon colonizing Canadian Arctic fresh waters containing native Arctic char.

\section{Conclusions}

The possible dispersal and establishment of Atlantic salmon in the Canadian Arctic is a matter of growing importance, as global temperatures increase and some northern rivers potentially become warm enough for Atlantic salmon colonization (Reist et al. 2006a). Arctic char are utilized in subsistence, recreational and commercial fisheries across the Canadian Arctic and are highly valued by the Inuit of Nunavut as a food resource and cultural staple (Kristofferson and Berkes 2005). The reduction or exclusion of Arctic char at the southern extent of their Canadian range would have considerable social, cultural and economic impact (Kristofferson and Berkes 2005; Reist et al. 2006a). Atlantic salmon are of similar importance both in ecological and economic terms (COSEWIC 2010) and could have significant effects on northern ecosystems (Reist et al. 2006a, b). While predicting northward distributional shifts of aquatic species remains useful, 
a greater understanding of the ecological implications of such biodiversity shifts is necessary in order to adequately prepare for and manage a future Arctic.

Acknowledgements This paper was written as part of the requirements for a Biological Sciences Co-op Degree for M. Bilous at the University of Manitoba. It benefited from reviews by Jim Reist, Darcy McNicholl, Colin Garroway, and three anonymous reviewers. We are grateful to Colin Garroway for providing support for M. Bilous during her co-op term. Funding support was provided by the Liber Ero Postdoctoral Fellowship Program, Fisheries and Oceans Canada, and Crown Indigenous Relations and Northern Affairs Canada. We also thank Angela Young and Zoya Martin (Government of Nunavut) for their assistance in providing various Nunavut Coastal Resource Inventory reports.

Open Access This article is licensed under a Creative Commons Attribution 4.0 International License, which permits use, sharing, adaptation, distribution and reproduction in any medium or format, as long as you give appropriate credit to the original author(s) and the source, provide a link to the Creative Commons licence, and indicate if changes were made. The images or other third party material in this article are included in the article's Creative Commons licence, unless indicated otherwise in a credit line to the material. If material is not included in the article's Creative Commons licence and your intended use is not permitted by statutory regulation or exceeds the permitted use, you will need to obtain permission directly from the copyright holder. To view a copy of this licence, visit http://creativecommons.org/licenses/by/4.0/.

\section{References}

Adams CE, Maitland PS (2001) Invasion and establishment of freshwater fish populations in Scotland-the experience of the past and lessons for the future. Glasg Nat 23:35-43

Amundsen PA, Knudsen R (2009) Winter ecology of Arctic charr (Salvelinus alpinus) and brown trout (Salmo trutta) in a subarctic lake, Norway. Aquat Ecol 43(3):765-775

April J, Hanner RH, Dion-Côté AM, Bernatchez L (2013) Glacial cycles as an allopatric speciation pump in northeastern American freshwater fishes. Mol Ecol 22(2):409-422

Arnekleiv JV, Davidsen JG, Sheehan TF, Lehnert SJ, Bradbury IR, Rønning L, Sjursen AD, Kjærstad G, Lubinski BA, Nilssen KJ (2019) Demographic and genetic description of Greenland's only indigenous Atlantic salmon Salmo salar population. J Fish Biol 94(1):154-164

Bardonnet A, Baglinière JL (2000) Freshwater habitat of Atlantic salmon (Salmo salar). Can J Fish Aquat Sci 57(2):497-506

Baroudy E, Elliott JM (1994) The critical thermal limits for juvenile Arctic charr Salvelinus alpinus. J Fish Biol 45(6): 1041-1053

Beddow TA, Deary C, McKinley RS (1998) Migratory and reproductive activity of radio-tagged Arctic char
(Salvelinus alpinus L.) in northern Labrador. Hydrobiologia 371:249-262

Bremset G (2000) Seasonal and diel changes in behaviour, microhabitat use and preferences by young pool-dwelling Atlantic salmon, Salmo salar, and brown trout, Salmo trutta. Environ Biol Fish 59(2):163-179

Chittenden CM, Fauchald P, Rikardsen AH (2013) Important open-ocean areas for northern Atlantic salmon (Salmo salar) — as estimated using a simple ambient-temperature approach. Can J Fish Aquat Sci 70(1):101-104

Chu C, Mandrak NE, Minns CK (2005) Potential impacts of climate change on the distributions of several common and rare freshwater fishes in Canada. Divers Distrib 11(4):299-310

Coates KS, Morrison WR (2001) Winter and the shaping of northern history: reflections from the Canadian North. In: Abel K, Coates KS (eds) Northern visions: new perspectives on the north in Canadian history. Broadview Press, Peterborough, pp 23-35

Coppinger R, Ryan W (1999) James Bay: environmental considerations for building large hydroelectric dams and reservoirs in Quebec. In: Hornig JF (ed) Social and Environmental Impacts of the James Bay Hydroelectric Project. McGill-Queen's Press, Montreal, pp 41-72

COSEWIC (2010) COSEWIC assessment and status report on the Atlantic salmon Salmo salar (Nunavik population, Labrador population, Northeast Newfoundland population, South Newfoundland population, Southwest Newfoundland population, Northwest Newfoundland population, Quebec Eastern North Shore population, Quebec Western North Shore population, Anticosti Island population, Inner St. Lawrence population, Lake Ontario population, GaspéSouthern Gulf of St. Lawrence population, Eastern Cape Breton population, Nova Scotia Southern Upland population, Inner Bay of Fundy population, Outer Bay of Fundy population) in Canada. Committee on the Status of Endangered Wildlife in Canada, Ottawa

Couturier CY, Clarke L, Sutterlin AM (1986) Identification of spawning areas of two forms of Atlantic salmon (Salmo salar L.) inhabiting the same watershed. Fish Res 4(2):131-144

Cunjak RA (1988) Behaviour and microhabitat of young Atlantic salmon (Salmo salar) during winter. Can J Fish Aquat Sci 45(12):2156-2160

Dempson JB, Shears M, Furey G, Bloom M (2008) Resilience and stability of north Labrador Arctic charr, Salvelinus alpinus, subject to exploitation and environmental variability. Environ Biol Fish 83(1):57-67

DFO (2012) Temperature threshold to define management strategies for Atlantic salmon (Salmo salar) fisheries under environmentally stressful conditions. DFO Can Sci Advis Sec Sci Advis Rep

Dunbar MJ (1970) On the fishery potential of the sea waters of the Canadian north. Arctic 23(3):150-174

Dunbar MJ, Hildebrand HH (1952) Contribution to the study of the fishes of Ungava Bay. J Fish Res Board Can 9(2):83-128

Dunmall KM, Reist JD, Carmack EC, Babaluk JA, Heide-Jørgensen MP, Docker MF (2013) Pacific salmon in the Arctic: harbingers of change. In: Mueter FJ, Dickson DMS, Huntington HP, Irvine JR, Logerwell EA, MacLean SA, 
Quakenbush LT, Rosa C (eds) Responses of arctic marine ecosystems to climate change. University of Alaska Fairbanks, Alaska Sea Grant, pp 141-160

Dunmall KM, Mochnacz NJ, Zimmerman CE, Lean C, Reist JD (2016) Using thermal limits to assess establishment of fish dispersing to high-latitude and high-elevation watersheds. Can J Fish Aquat Sci 73(12):1750-1758

Dunmall KM, McNicholl DG, Reist JD (2018) Communitybased monitoring demonstrates increasing occurrences and abundances of Pacific salmon in the Canadian Arctic from 2000 to 2017. In: Pacific salmon production in a changing climate, Khabarovsk, Russia, May 2018 North Pacific Anadromous Fish Commission, Vancouver, BC, pp 87-90

Einarsson SM, Mills DH, Johannsson V (1990) Utilisation of fluvial and lacustrine habitat by anadromous Atlantic salmon, Salmo salar L., in an Icelandic watershed. Fish Res 10:53-71

Elliott JM (1991) Tolerance and resistance to thermal stress in juvenile Atlantic salmon, Salmo salar. Freshw Biol 25(1):61-70

Elliott JM, Baroudy E (1995) The ecology of Arctic charr, Salvelinus alpinus, and brown trout, Salmo trutta, in Windermere (northwest England). Nord J Freshw Res 71:33-48

Elliott J, Elliott JA (2010) Temperature requirements of Atlantic salmon Salmo salar, brown trout Salmo trutta and Arctic charr Salvelinus alpinus: predicting the effects of climate change. J Fish Biol 77(8):1793-1817

Elliott JM, Klemetsen A (2002) The upper critical thermal limits for alevins of Arctic charr from a Norwegian lake north of the Arctic circle. J Fish Biol 60(5):1338-1341

Erkinaro J, Niemelä E, Shustov Y (1998) Feeding strategies of Atlantic salmon Salmo salar parr occupying lacustrine and fluvial habitats in a subarctic river, northern Finland. Pol Arch Hydrobiol 45(2):259-268

Fernandes JA, Cheung WW, Jennings S, Butenschön M, de Mora L, Frölicher TL, Barange M, Grant A (2013) Modelling the effects of climate change on the distribution and production of marine fishes: accounting for trophic interactions in a dynamic bioclimate envelope model. Glob Chang Biol 19(8):2596-2607

Finstad AG, Hein CL (2012) Migrate or stay: terrestrial primary productivity and climate drive anadromy in Arctic char. Glob Chang Biol 18(8):2487-2497

Finstad AG, Næsje TF, Forseth T (2004) Seasonal variation in the thermal performance of juvenile Atlantic salmon (Salmo salar). Freshw Biol 49(11):1459-1467

Fisheries and Oceans Canada (2018) Guide to identifying Salmon and Char in the Arctic, 3rd edn. Vecsei P, Dunmall K, McNicholl D, Reist J, p 26

Fletcher GL, Kao MH, Dempson JB (1988) Lethal freezing temperatures of Arctic char and other salmonids in the presence of ice. Aquaculture 71(4):369-378

Friedland KD, Reddin DG, McMenemy JR, Drinkwater KF (2003) Multidecadal trends in North American Atlantic salmon (Salmo salar) stocks and climate trends relevant to juvenile survival. Can J Fish Aquat Sci 60(5):563-583

Gilbert MJ, Tierney KB (2018) Warm northern river temperatures increase post-exercise fatigue in an Arctic migratory salmonid but not in a temperate relative. Funct Ecol 32(3):687-700
Government of Nunavut (2009) Nunavut coastal resource inventory-Kimmirut. Department of Environment, Fisheries and Sealing Division, Iqaluit, Nunavut. https://www. gov.nu.ca/sites/default/files/ncri_kimmirut_en.pdf. Accessed 18 June 2019

Government of Nunavut (2010) Nunavut coastal resource inventory-Kugluktuk. Department of Environment, Fisheries and Sealing Division, Iqaluit, Nunavut. https:// www.gov.nu.ca/sites/default/files/ncri_kugluktuk_en.pdf. Accessed 18 June 2019

Government of Nunavut (2012a) Nunavut coastal resource inventory-Coral Harbour. Department of Environment, Fisheries and Sealing Division, Iqaluit, Nunavut. https:// www.gov.nu.ca/sites/default/files/ncri_coral_harbour_en. pdf. Accessed 18 June 2019

Government of Nunavut (2012b) Nunavut coastal resource inventory-Iqaluit. Department of Environment, Fisheries and Sealing Division, Iqaluit, Nunavut. https://www.gov. nu.ca/sites/default/files/ncri_iqaluit_en.pdf. Accessed 18 June 2019

Government of Nunavut (2013) Nunavut coastal resource inventory-Pangnirtung. Department of Environment, Fisheries and Sealing Division, Iqaluit, Nunavut. https:// www.gov.nu.ca/sites/default/files/ncri_pangnirtung_en_0. pdf. Accessed 18 June 2019

Government of Nunavut (2014) Nunavut coastal resource inventory-Clyde River. Department of Environment, Fisheries and Sealing Division, Iqaluit, Nunavut. https:// www.gov.nu.ca/sites/default/files/ncri_clyde_river_en. pdf. Accessed 18 June 2019

Government of Nunavut (2015a) Nunavut coastal resource inventory-Cambridge Bay. Department of Environment, Fisheries and Sealing Division, Iqaluit, Nunavut. https:// www.gov.nu.ca/sites/default/files/ncri_cambridge_bay_ en.pdf. Accessed 18 June 2019

Government of Nunavut (2015b) Nunavut coastal resource inventory-Kugaaruk. Department of Environment, Fisheries and Sealing Division, Iqaluit, Nunavut. https://www. gov.nu.ca/sites/default/files/ncri_kugaaruk_en.pdf. Accessed 18 June 2019

Grønvik S, Klemetsen A (1987) Marine food and diet overlap of co-occurring Arctic charr Salvelinus alpinus (L.), brown trout Salmo trutta L. and Atlantic salmon S. salar L. off Senja, N. Norway. Polar Biol 7(3):173-177

Gunnarsson GS, Steingrímsson SÓ (2011) Contrasting patterns of territoriality and foraging mode in two stream-dwelling salmonids, Arctic char (Salvelinus alpinus) and brown trout (Salmo trutta). Can J Fish Aquat Sci 68(12):2090-2100

Halvorsen M, Jørgensen L (1996) Lake-use by juvenile Atlantic salmon (Salmo salar L.) and other salmonids in northern Norway. Ecol Freshw Fish 5(1):28-36

Halvorsen M, Jørgensen L, Amundsen PA (1997) Habitat utilization of juvenile Atlantic salmon (Salmo salar L.), brown trout (Salmo trutta L.) and Arctic charr (Salvelinus alpinus (L.)) in two lakes in northern Norway. Ecol Freshw Fish 6(2):67-77

Hamilton J, Wu Y (2013) Synopsis and trends in the physical environment of Baffin Bay and Davis Strait. Can Tech Rep Hydrogr Ocean Sci 282 
Harwood LA, Babaluk JA (2014) Spawning, overwintering and summer feeding habitats used by anadromous Arctic char (Salvelinus alpinus) of the Hornaday River, Northwest Territories, Canada. Arctic 67(4):449-461

Hattab T, Albouy C, Lasram FBR, Somot S, Le Loc'h F, Leprieur F (2014) Towards a better understanding of potential impacts of climate change on marine species distribution: a multiscale modelling approach. Glob Ecol Biogeogr 23(12):1417-1429

Heath AG, Turner BJ, Davis WP (1993) Temperature preferences and tolerances of three fish species inhabiting hyperthermal ponds on mangrove islands. Hydrobiologia 259(1):47-55

Hedeholm RB, Broberg M, Nygaard R, Grønkjær P (2018) Population decline in the endemic Atlantic salmon (Salmo salar) in Kapisillit River, Greenland. Fish Manag Ecol 25(5):392-399

Heggberget TG (1984) Habitat selection and segregation of parr of Arctic charr (Salvelinus alpinus), brown trout (Salmo trutta) and Atlantic salmon (Salmo salar L.) in two streams in North Norway. In: Biology of the Arctic charr: proceedings of the international symposium on Arctic charr, Winnipeg, Manitoba, May 1981. University of Manitoba Press, Winnipeg, Manitoba, pp 217-231

Heggberget TG, Haukebø T, Mork J, Ståhl G (1988) Temporal and spatial segregation of spawning in sympatric populations of Atlantic salmon, Salmo salar L., and brown trout, Salmo trutta L. J Fish Biol 33(3):347-356

Heggenes J, Saltveit SJ (2007) Summer stream habitat partitioning by sympatric Arctic charr, Atlantic salmon and brown trout in two sub-arctic rivers. J Fish Biol 71(4):1069-1081

Hein CL, Öhlund G, Englund G (2012) Future distribution of Arctic char Salvelinus alpinus in Sweden under climate change: effects of temperature, lake size and species interactions. Ambio 41(3):303-312

Hickling R, Roy DB, Hill JK, Fox R, Thomas CD (2006) The distributions of a wide range of taxonomic groups are expanding polewards. Glob Chang Biol 12(3):450-455

Holierhoek AM, Power G (1995) Responses of wild juvenile Arctic char to cover, light and predator threat. Nordic J Freshw Res 71:296-308

Holm JC (1989) Mono-and duoculture of juvenile Atlantic salmon (Salmo salar) and Arctic char (Salvelinus alpinus). Can J Fish Aquat Sci 46(4):697-704

Huntsman AG (1942) Death of salmon and trout with high temperature. J Fish Res Board Can 5(5):485-501

Hurst TP (2007) Causes and consequences of winter mortality in fishes. J Fish Biol 71(2):315-345

ICES (2019) Working group on North Atlantic salmon (WGNAS). ICES Scientific Reports, International Council for the Exploration of the Sea, Copenhagen, Denmark

IPCC (2014) Climate change 2014: synthesis report. In: Core Writing Team, Pachauri RK, Meyer LA (eds) Contribution of working groups I, II and III to the fifth assessment report of the intergovernmental panel on climate change. IPCC, Geneva, Switzerland

Janjua MY, Etuangat J, Sudlovenick E, Martin Z, Tallman RF, Friesen M, Carmichael T (2016) Results from a traditional ecological knowledge study on Arctic char in Qikiqtarjuaq (Nunavut) fishing areas. Can Manuscr Rep Fish Aquat Sci
3090, Central and Arctic Region, Fisheries and Oceans Canada, Winnipeg, MB

Jensen JM (1990) Atlantic salmon at Greenland. Fish Res 10:29-52

Jensen AJ, Finstad B, Fiske P, Hvidsten NA, Rikardsen AH, Saksgård L (2012) Timing of smolt migration in sympatric populations of Atlantic salmon (Salmo salar), brown trout (Salmo trutta), and Arctic char (Salvelinus alpinus). Can J Fish Aquat Sci 69(4):711-723

Jeppesen E, Mehner T, Winfield IJ, Kangur K, Sarvala J, Gerdeaux D, Rask M, Malmquist HJ, Holmgren K, Volta P, Romo S, Eckmann R, Sandström A, Blanco S, Kangur A, Stabo HR, Tarvainen M, Ventelä A-M, Søndergaard M, Lauridsen TL, Meerhoff M (2012) Impacts of climate warming on the long-term dynamics of key fish species in 24 European lakes. Hydrobiologia 694(1):1-39

Jessop BM, Lee RLG, Power G (1970) Observations on the fish fauna of the Leaf River, Ungava. Can Field-Nat 84:365-367

Jeuthe H, Brännäs E, Nilsson J (2016) Effects of variable egg incubation temperatures on the embryonic development in Arctic charr Salvelinus alpinus. Aquac Res 47(12):3753-3764

Johansen M, Erkinaro J, Amundsen P-A (2011) The when, what and where of freshwater feeding. In: Aas Ø, Klemetsen A, Einum S, Skurdal J (eds) Atlantic salmon ecology. Wiley, West Sussex, pp 89-114

Johnson L (1980) The arctic charr, Salvelinus alpinus. In: Balon EK (ed) Charrs: Salmonid Fishes of the Genus Salvelinus. Dr. W. Junk bv Publishers, The Hague, pp 15-98

Jonsson B, Jonsson N (2001) Polymorphism and speciation in Arctic charr. J Fish Biol 58(3):605-638

Jonsson B, Jonsson N (2009) A review of the likely effects of climate change on anadromous Atlantic salmon Salmo salar and brown trout Salmo trutta, with particular reference to water temperature and flow. J Fish Biol 75(10):2381-2447

Jonsson B, Jonsson N (2011) Ecology of Atlantic salmon and brown trout: habitat as a template for life histories. Fish and Fisheries No. 33

Jonsson B, Forseth T, Jensen AJ, Næsje TF (2001) Thermal performance of juvenile Atlantic salmon, Salmo salar L. Funct Ecol 15(6):701-711

Jørgensen EH, Johnsen HK (2014) Rhythmic life of the Arctic charr: adaptations to life at the edge. Mar Genom 14:71-81

Jørgensen L, Halvorsen M, Amundsen PA (2000) Resource partitioning between lake-dwelling Atlantic salmon (Salmo salar L.) parr, brown trout (Salmo trutta L.) and Arctic charr (Salvelinus alpinus (L.)). Ecol Freshw Fish 9(4):202-209

Kazakov RV, Veselov AJ (1998) Atlantic salmon (Salmo salar L.) catches in Russia. J Appl Ichthyol 14(1-2):65-68

King TL, Kalinowski ST, Schill WB, Spidle AP, Lubinski BA (2001) Population structure of Atlantic salmon (Salmo salar L.): a range-wide perspective from microsatellite DNA variation. Mol Ecol 10(4):807-821

Klemetsen A, Amundsen PA, Dempson JB, Jonsson B, Jonsson N, O'Connell MF, Mortensen E (2003a) Atlantic salmon Salmo salar L., brown trout Salmo trutta L. and Arctic charr Salvelinus alpinus (L.): a review of aspects of their life histories. Ecol Freshw Fish 12(1):1-59 
Klemetsen A, Knudsen R, Staldvik FJ, Amundsen PA (2003b) Habitat, diet and food assimilation of Arctic charr under the winter ice in two subarctic lakes. J Fish Biol 62(5):1082-1098

Kristofferson AH, Berkes F (2005) Adaptive co-management of Arctic char in Nunavut Territory. In: Berkes F, Huebert R, Fast H, Manseau M, Diduck A (eds) Breaking ice: renewable resource and ocean management in the Canadian North. University of Calgary Press, Calgary, pp 249-268

Langeland A, L'Abée-Lund JH, Jonsson B, Jonsson N (1991) Resource partitioning and niche shift in Arctic charr Salvelinus alpinus and brown trout Salmo trutta. J Anim Ecol 60(3):895-912

Larsson S, Forseth T, Berglund I, Jensen AJ, Näslund I, Elliott JM, Jonsson B (2005) Thermal adaptation of Arctic charr: experimental studies of growth in eleven charr populations from Sweden, Norway and Britain. Freshw Biol 50(2):353-368

Last PR, White WT, Gledhill DC, Hobday AJ, Brown R, Edgar GJ, Pecl G (2011) Long-term shifts in abundance and distribution of a temperate fish fauna: a response to climate change and fishing practices. Glob Ecol Biogeogr 20(1):58-72

Lee RLG, Power G (1976) Atlantic salmon (Salmo salar) of the Leaf river, Ungava Bay. J Fish Res Board Can 33(11):2616-2621

Linnansaari T, Cunjak RA (2010) Patterns in apparent survival of Atlantic salmon (Salmo salar) parr in relation to variable ice conditions throughout winter. Can J Fish Aquat Sci 67(11):1744-1754

Louhi P, Mäki-Petäys A, Erkinaro J (2008) Spawning habitat of Atlantic salmon and brown trout: general criteria and intragravel factors. River Res Appl 24(3):330-339

MacCrimmon HR, Gots BL (1979) World distribution of Atlantic salmon, Salmo salar. J Fish Res Board Can 36(4):422-457

Maitland PS (1995) World status and conservation of the arctic charr Salvelinus alpinus (L.). Nordic J Freshw Res 71:113-127

Mäki-Petäys A, Huusko A, Erkinaro J, Muotka T (2002) Transferability of habitat suitability criteria of juvenile Atlantic salmon (Salmo salar). Can J Fish Aquat Sci 59(2):218-228

Makhrov AA, Verspoor E, Artamonova VS, O'Sullivan M (2005) Atlantic salmon colonization of the Russian Arctic coast: pioneers from North America. J Fish Biol 67:68-79

Mills D (1989) Ecology and management of Atlantic salmon. Chapman and Hall Ltd, London

Milner AM, Bailey RG (1989) Salmonid colonization of new streams in Glacier Bay National park, Alaska. Aquac Res 20(2):179-192

Milner AM, Fastie CL, Chapin FS, Engstrom DR, Sharman LC (2007) Interactions and linkages among ecosystems during landscape evolution. Bioscience 57(3):237-247

Milner AM, Robertson AL, Monaghan KA, Veal AJ, Flory EA (2008) Colonization and development of an Alaskan stream community over 28 years. Front Ecol Environ $6(8): 413-419$

Milner NJ, Solomon DJ, Smith GW (2012) The role of river flow in the migration of adult Atlantic salmon, Salmo salar, through estuaries and rivers. Fish Manag Ecol 19(6):537-547

Moore JW (1975) Reproductive biology of anadromous arctic char, Salvelinus alpinus (L.), in the Cumberland Sound area of Baffin Island. J Fish Biol 7:143-151

Moore A, Bendall B, Barry J, Waring C, Crooks N, Crooks L (2012) River temperature and adult anadromous Atlantic salmon, Salmo salar, and brown trout, Salmo trutta. Fish Manag Ecol 19(6):518-526

Moore JS, Loewen TN, Harris LN, Tallman RF (2014) Genetic analysis of sympatric migratory ecotypes of Arctic charr Salvelinus alpinus: alternative mating tactics or reproductively isolated strategies? J Fish Biol 84(1):145-162

Morin R (1991) Atlantic salmon (Salmo salar) in the lower Nastapoka River, Quebec: distribution and origins of salmon in eastern Hudson Bay. Can J Zool 69:1674-1681

Nielsen JG (1961) Contributions to the Biology of the Salmonidae in Greenland, I-IV. Medd Gronl 159:1-75

Nielsen JL, Ruggerone GT, Zimmerman CE (2013) Adaptive strategies and life history characteristics in a warming climate: Salmon in the Arctic? Environ Biol Fish 96(10-11):1187-1226

Nilsson J, Gross R, Asplund T, Dove O, Jansson H, Kelloniemi J, Kohlmann K, Löytynoja A, Nielsen EE, Paaver T, Primmer CR (2001) Matrilinear phylogeography of Atlantic salmon (Salmo salar L.) in Europe and postglacial colonization of the Baltic Sea area. Mol Ecol 10(1):89-102

O'Connell MF, Dempson JB (1996) Spatial and temporal distributions of salmonids in two ponds in Newfoundland, Canada. J Fish Biol 48(4):738-757

Parmesan C (2006) Ecological and evolutionary responses to recent climate change. Annu Rev Ecol Evol Syst 37:637-669

Perry AL, Low PJ, Ellis JR, Reynolds JD (2005) Climate change and distribution shifts in marine fishes. Science 308(5730):1912-1915

Pess GR, Quinn TP, Gephard SR, Saunders R (2014) Re-colonization of Atlantic and Pacific rivers by anadromous fishes: linkages between life history and the benefits of barrier removal. Rev Fish Biol Fish 24(3):881-900

Poloczanska ES, Burrows MT, Brown CJ, García Molinos J, Halpern BS, Hoegh-Guldberg O, Kappel CV, Moore PJ, Richardson AJ, Schoeman DS, Sydeman WJ (2016) Responses of marine organisms to climate change across oceans. Front Mar Sci 3(62):1-21

Pörtner HO, Farrell AP (2008) Physiology and climate change. Science 322(5902):690-692

Power G (1958) The evolution of the freshwater races of the Atlantic salmon (Salmo salar L.) in eastern North America. Arctic 11(2):86-92

Power M, Reist JD (2018) Salvelinus alpinus. In: Coad BW, Reist JD (eds) Marine fishes of Arctic Canada. University of Toronto Press, Toronto, pp 283-289

Power G, Brown RS, Imhof JG (1999) Groundwater and fishinsights from northern North America. Hydrol Process 13(3):401-422

Read CJ (2000) Information from arctic charr fisheries in the baffin region, nunavut, 1995 to 1999. Can Data Rep Fish Aquat Sci 1067:1-176

Reist JD, Wrona FJ, Prowse TD, Power M, Dempson JB, King JR, Beamish RJ (2006a) An overview of effects of climate 
change on selected Arctic freshwater and anadromous fishes. Ambio 35(7):381-387

Reist JD, Wrona FJ, Prowse TD, Power M, Dempson JB, Beamish RJ, King JR, Carmichael TJ, Sawatzky CD (2006b) General effects of climate change on Arctic fishes and fish populations. Ambio 35(7):370-380

Richardson ES, Reist JD, Minns CK (2001) Life history characteristics of freshwater fishes occurring in the Northwest Territories and Nunavut, with major emphasis on lake habitat requirements. Can Manuscr Rep Fish Aquat Sci 2569, Central and Arctic Division, Fisheries and Oceans Canada, Winnipeg, MB

Rimmer DM, Paim U, Saunders RL (1984) Changes in the selection of microhabitat by juvenile Atlantic salmon (Salmo salar) at the summer-autumn transition in a small river. Can J Fish Aquat Sci 41(3):469-475

Robitaille JA, Côté Y, Shooner G, Hayeur G (1986) Growth and maturation patterns of Atlantic salmon, Salmo salar, in the Koksoak River, Ungava, Quebec. Can Spec Publ Fish Aquat Sci 89:62-69

Rubin JF (2005) Les sites de reproduction de l'omble chevalier du Léman. Arch Sci 58:201-230

Salisbury SJ, Booker C, McCracken GR, Knight T, Keefe D, Perry R, Ruzzante DE (2018) Genetic divergence among and within Arctic char (Salvelinus alpinus) populations inhabiting landlocked and sea-accessible sites in Labrador, Canada. Can J Fish Aquat Sci 75(8):1256-1269

Salonius PO (1973) Barriers to range extension of Atlantic and Pacific salmon in arctic North America. Arctic 26(2):112-122

Schindler DW (2001) The cumulative effects of climate warming and other human stresses on Canadian freshwaters in the new millennium. Can J Fish Aquat Sci 58(1):18-29

Scott WB, Crossman EJ (1973) Freshwater fishes of Canada. Bull Fish Res Board Can No. 184

Sinnatamby RN, Babaluk JA, Power G, Reist JD, Power M (2012) Summer habitat use and feeding of juvenile Arctic charr, Salvelinus alpinus, in the Canadian High Arctic. Ecol Freshw Fish 21:309-322

Somero GN, DeVries AL (1967) Temperature tolerance of some Antarctic fishes. Science 156(3772):257-258

Sunday JM, Bates AE, Dulvy NK (2012) Thermal tolerance and the global redistribution of animals. Nat Clim Chang 2(9):686-690

Sunday JM, Pecl GT, Frusher S, Hobday AJ, Hill N, Holbrook NJ, Edgar GJ, Stuart-Smith R, Barrett N, Wernberg T, Watson RA, Smale DA, Fulton EA, Slawinski D, Feng M, Radford BT, Thompson PA, Bates AE (2015) Species traits and climate velocity explain geographic range shifts in an ocean-warming hotspot. Ecol Lett 18:944-953

Svenning MA, Klemetsen A, Olsen T (2007) Habitat and food choice of Arctic charr in Linnévatn on Spitsbergen,
Svalbard: the first year-round investigation in a High Arctic lake. Ecol Freshw Fish 16(1):70-77

Svenning MA, Sandem K, Halvorsen M, Kanstad-Hanssen $\varnothing$, Falkegård M, Borgstrøm R (2016) Change in relative abundance of Atlantic salmon and Arctic charr in Veidnes River, Northern Norway: a possible effect of climate change? Hydrobiologia 783(1):145-158

Thorstad EB, Whoriskey F, Rikardsen AH, Aarestrup K (2011) Aquatic nomads: the life and migrations of the Atlantic salmon. In: Aas $\varnothing$, Klemetsen A, Einum S, Skurdal J (eds) Atlantic salmon ecology. Wiley, West Sussex, pp 1-32

Tingley MW, Monahan WB, Beissinger SR, Moritz C (2009) Birds track their Grinnellian niche through a century of climate change. Proc Natl Acad Sci 106(Supplement 2):19637-19643

Todd CD, Friedland KD, MacLean JC, Hazon N, Jensen AJ (2011) Getting into hot water? Atlantic salmon responses to climate change in freshwater and marine environments. In: Aas Ø, Klemetsen A, Einum S, Skurdal J (eds) Atlantic salmon ecology. Wiley, West Sussex, pp 409-443

Tunney TD, Steingrímsson SÓ (2012) Foraging mode variation in three stream-dwelling salmonid fishes. Ecol Freshw Fish 21(4):570-580

Vincent WF, Laurion I, Pienitz R, Walter Anthony KM (2013) Climate impacts on Arctic lake ecosystems. In: Goldman CR, Kumagai M, Robarts RD (eds) Climatic change and global warming of inland waters: impacts and mitigation for ecosystems and societies. Wiley, Chichester, pp 27-42

Volobuev VV (1973) Contribution to the biology of diadromous char (Salvelinus) in certain rivers of northern Okhotsk coast area. Trans Pac Ocean Sci Res Inst Fish Oceanogr 86:119-130

Wallace JC, Heggberget TG (1988) Incubation of eggs of Atlantic salmon (Salmo salar) from different Norwegian streams at temperatures below 1 C. Can J Fish Aquat Sci 45(1):193-196

Waples RS, Pess GR, Beechie T (2008) Evolutionary history of Pacific salmon in dynamic environments. Evol Appl 1(2):189-206

Yoon S, Watanabe E, Ueno H, Kishi MJ (2015) Potential habitat for chum salmon (Oncorhynchus keta) in the Western Arctic based on a bioenergetics model coupled with a three-dimensional lower trophic ecosystem model. Prog Oceanogr 131:146-158

Young A (2019) Anadromy versus non-anadromy in the Canadian Arctic: variation in the lake ecology and life history of two allopatric Arctic charr (Salvelinus alpinus) populations in Cumberland Sound on South Baffin Island, Nunavut. Thesis, University of Manitoba

Publisher's Note Springer Nature remains neutral with regard to jurisdictional claims in published maps and institutional affiliations. 